\title{
Variedades da Democracia no Brasil
}

Fernando Bizzarro ${ }^{1}$

Michael Coppedge

\section{Introdução ${ }^{2}$}

Um dos grandes desafios da ciência política é medir e analisar corretamente os fenômenos de natureza complexa e multifacetada que compõem o objeto da disciplina. Os principais desses objetos - a natureza, a causa e as consequências dos regimes políticos - sofrem em especial com os desafios de mensuração e análise. Regimes políticos são multifacetados, compostos por diversas práticas, instituições e atores. Eles são também o resultado do desenvolvimento histórico e das disputas políticas pelas quais se constroem o Estado Nacional e as instituições políticas em um país, podendo ser internamente contraditórios, combinando, por exemplo, características associadas com regimes mais democráticos a características típicas de contextos autoritários.

Este artigo apresenta ao público de língua portuguesa alguns resultados do projeto Variedades da Democracia ${ }^{3}$, um projeto internacional que visa oferecer aos pesquisadores e formuladores de políticas públicas interessados em instituições e regimes políticos uma ferramenta consistente e abrangente para a mensuração e a análise das diferentes dimensões dos regimes políticos. Para ilustrar as principais características dos dados coletados pelo projeto, neste artigo nós descrevemos em profundidade os resultados obtidos para o Brasil.

Mais que promover qualquer mudança nas interpretações existentes sobre a democracia brasileira, este artigo ambiciona demonstrar a utilidade dos dados do projeto Variedades da Democracia para a pesquisa empírica em ciência política, explicitando o alcance de suas múltiplas dimensões, a sua capacidade de sintetizar as importantes transformações que o país experimentou e o largo potencial comparativo dos dados do

\footnotetext{
${ }^{1}$ Autores ordenados alfabeticamente.

2 Os dados deste artigo foram apresentados previamente por Michael Coppedge em conferência homônima na Universidade Federal de Goiás, em junho de 2015. Nós agradecemos aos participantes do seminário pelos seus comentários e observações, a Sergio Praça e a todos os especialistas que colaboraram com o projeto Variedades da Democracia no Brasil. Somos gratos também pelo generoso financiamento do Riksbankens Jubileumsfond; da Comissão Europeia; da Fundação Wallenberg; dos Ministérios de Relações Exteriores de Suécia, Canadá e Dinamarca; dos conselhos de pesquisa da Suécia, Noruega e Dinamarca; da National Science Foundation; das Universidades de Gotemburgo e Notre Dame, e da Pontifícia Universidade Católica de Chile; da International IDEA; e do Quality of Government Institute da Universidade de Gotemburgo. Nós agradecemos aos revisores anônimos por seus comentários.

${ }^{3}$ Conferir: <http://v-dem.net>.
} 
VARIEDADES DA DEMOCRACIA NO BRASIL

projeto, que cobrem praticamente todos os países do mundo por mais de 100 anos. Ao mesmo tempo, o artigo pode servir como síntese e introdução à história dos regimes políticos no Brasil, sendo utilizado por pesquisadores e estudantes que queiram observar a evolução da democracia no país.

$\mathrm{O}$ artigo se divide em seis seções além desta Introdução. Na primeira seção, "O projeto Variedades da Democracia", apresentamos o projeto (doravante chamado apenas de V-Dem). Na seção seguinte, "Democracia eleitoral", exploramos os indicadores de democracia eleitoral no Brasil para o período 1900-2015. Na terceira seção, "Outras dimensões da democracia brasileira", analisamos os dados recolhidos pelo projeto para outras dimensões da democracia brasileira no mesmo período. Na quarta, "Dimensões adjacentes à democracia: corrupção e partidos políticos", apresentamos informações sobre essas dimensões do regime político no Brasil. Em "Um exercício comparativo: o Brasil e seus vizinhos", comparamos o Brasil com outros países sul-americanos. A Conclusão sintetiza as principais tendências e achados apresentados neste artigo.

\section{O projeto Variedades da Democracia}

A democracia é um conceito multidimensional (Munck Verkuilen, 2002) e que se encontra em constante transformação. Ela é também um dos pilares da análise da política desde a Grécia Antiga (Held, 1987), sendo central para a ciência política moderna como disciplina. As diferenças nas perspectivas dos teóricos e cientistas políticos, quando existem, estão normalmente concentradas na definição daquelas que são consideradas as dimensões necessárias da democracia (Coppedge, 2012). Enquanto vários autores defendem a primazia da dimensão eleitoral, ilustrada pela presença de eleições livres, justas e decisivas (Dahl, 1971; Schumpeter, 2013), outros argumentam que regimes políticos democráticos incluem dimensões que se expandem para além dos limites da competição eleitoral (Held, 1987; Lijphart, 1999).

O V-Dem adota a perspectiva de que para a melhor observação e compreensão das possibilidades de "governo do povo" - uma mínima definição de democracia da qual poucos discordam - é necessária a construção de indicadores abrangentes das possíveis diferentes dimensões do regime, permitindo aos pesquisadores e interessados enfocar suas análises nas dimensões mais apropriadas para seus objetivos e referenciais teóricos (Coppedge et al., 2011). Por causa disso, o V-Dem oferece indicadores das cinco principais dimensões dos regimes democráticos discutidos pela literatura especializada: dimensão eleitoral, liberal, participativa, deliberativa e igualitária (Coppedge et al., 2016a).

Algumas dessas dimensões, sobretudo as dimensões eleitoral e liberal, já foram capturadas pelos indicadores existentes (Coppedge et al., 2011; Munck e Verkuilen, 2002). O projeto Variedades da Democracia inova ao oferecer para os pesquisadores em ciência política uma nova geração de indicadores de democracia. Guiado pelos princípios da multidimensionalidade da democracia, da desagregação dos indicadores e da 
transparência na coleta e publicação dos dados, ele visa superar os principais limites dos indicadores existentes: sua pouca abrangência conceitual, geralmente concentrados nas dimensões eleitoral e liberal (direitos civis e políticos) dos regimes políticos; seu limitado alcance geográfico e temporal, que raramente cobre países não localizados na região do Atlântico Norte por longos períodos de tempo; e sua falta de transparência, dado que regras de classificação são raramente públicas e consistentes (Coppedge et al., 2011) ${ }^{4}$.

A Figura 1 ilustra a multidimensionalidade e a natureza desagregada dos dados recolhidos pelo projeto. Ela inclui um mapa de parte dos índices e indicadores ${ }^{5}$ contidos no projeto. Inicialmente, o V-Dem desagregou o macroconceito de democracia em suas dimensões eleitoral, liberal, participativa, igualitária e deliberativa. Concentrando nossa observação na dimensão eleitoral da democracia, podemos desagregar esse componente para observar que ele possui diferentes subdimensões. Essas subdimensões incluem os principais elementos presentes em definições "procedimentais da democracia" (Coppedge, 2012), como a presença de eleições livres e justas, de eleições populares (diretas ou indiretas) do Poder Executivo, de um sufrágio abrangente, além de índices medindo liberdades de associação e de expressão. Cada uma dessas subdimensões é medida por indicadores precisos e específicos, incluindo, por exemplo, medidas de quão comum é a compra de votos, a repressão à sociedade civil ou as tentativas de censura da imprensa. Tal desenho de pesquisa permite obter indicadores apurados de características particulares dos regimes políticos e também possibilita a agregação desses indicadores em índices consistentes, teórica e empiricamente robustos, de dimensões mais complexas da democracia.

\footnotetext{
${ }^{4}$ Para informações sobre o projeto e download dos dados, ver em: <http://v-dem.net>. Acesso em: 30 mar. 2017. Ferramentas online permitem a visualização e a produção de gráficos semelhantes aos encontrados neste artigo. Para mais informações sobre os dados do projeto, ver a documentação online. ${ }^{5}$ Indicadores são os elementos básicos presentes no banco de dados do V-Dem, constituídos pela tradução das respostas que os codificadores do V-Dem deram às perguntas a eles apresentadas em variáveis contínuas usadas para a visualização dos resultados. Índices são agregações de indicadores. Todos os índices são formados a partir de uma análise fatorial bayesiana que reduz os indicadores incluídos em cada índice a um único valor.
} 


\section{Figura 1 \\ Exemplo de indicadores e agregações no banco de dados do V-Dem (democracia liberal)}

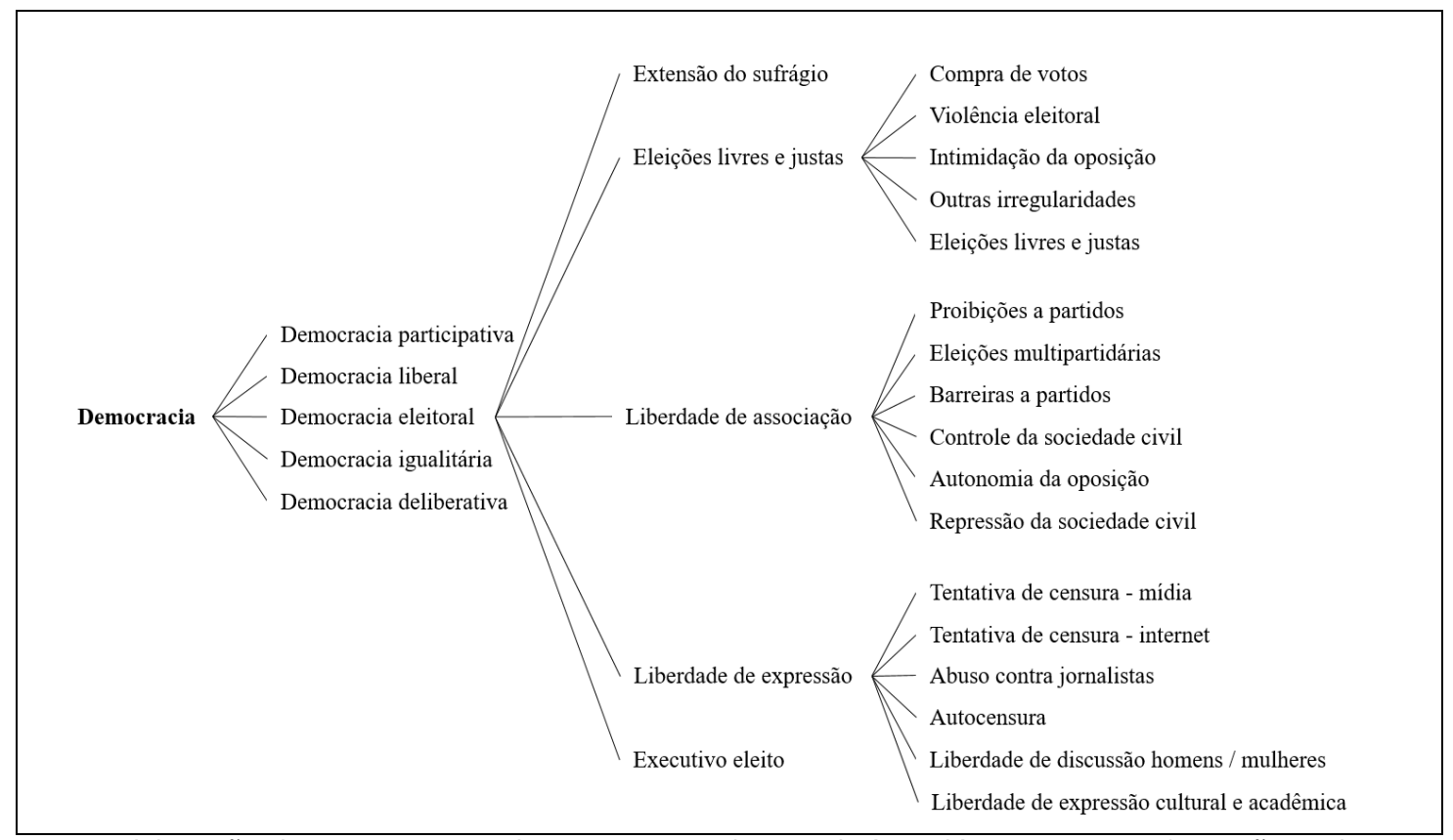

Fonte: Elaboração dos autores, com base em Coppedge et al. (2016b). Para mais informações sobre os indicadores, índices e regras de agregação, veja essa referência.

O V-Dem é um projeto baseado em surveys com especialistas (expert surveys). Mais de 2.600 pesquisadores de todo o mundo foram solicitados a responder questões sobre diferentes indicadores de democracia. Tais pesquisadores foram selecionados pela direção do projeto, sediada nas universidades de Notre Dame, nos Estados Unidos, e Gotemburgo, na Suécia, após recomendações de especialistas - baseados tanto no interior do país quanto no exterior - para a atuação como "codificadores" para o V-Dem (Coppedge et al., 2016c).

As perguntas que os pesquisadores participantes responderam consistiram normalmente de questões categóricas que ofereciam parâmetros precisos e comparáveis para análise das múltiplas dimensões dos regimes políticos para os vários países pesquisados (Coppedge et al., 2016b). Para garantir a comparabilidade, todas as perguntas foram respondidas para todos os países por um mínimo de três codificadores por país para todos os anos incluídos no projeto (1900-2015). Em seguida, os dados coletados a partir das respostas oferecidas pelos especialistas foram agregados para formar uma única estimativa para cada país em um determinado ano, utilizando-se um modelo de medida construído pela aplicação de novas técnicas de agregação baseadas em um modelo bayesiano para teoria da resposta-item (Pemstein, Tzelgov e Wang, 
2015) ${ }^{6}$. Tal estratégia está alinhada com as mais modernas recomendações para o tratamento de surveys com especialistas disponíveis.

A Figura 2 contém um exemplo de uma das questões contidas no projeto. Ela buscava capturar a ocorrência de intimidação por parte do governo contra a oposição durante eleições. As respostas possíveis são divididas em cinco categorias, progredindo das situações menos democráticas para as mais democráticas, e buscando englobar uma miríade de situações exemplares às quais os codificadores podem associar seu conhecimento da realidade de um país e avaliar em qual das categorias aquele país se encaixa naquele ano. Na categoria mínima, incluem-se situações de repressão absoluta da oposição, como as experiências eleitorais na extinta União Soviética. Na segunda categoria, níveis elevados de repressão nos quais a oposição sofre intimidação sistemática por parte de agentes do governo estão descritos. No caso brasileiro, as eleições de 1970 são classificadas no banco de dados do V-Dem como pertencentes a essa categoria. As eleições de 1970 ocorreram no auge dos "anos de chumbo" do regime militar brasileiro, com múltiplas evidências de perseguição e intimidação dos candidatos da oposição por parte de agentes do regime (Kinzo, 1988).

\section{Figura 2 \\ Exemplo de pergunta incluída no questionário do V-Dem}

\section{Intimidação governamental durante as eleições}

Questão: Nesta eleição nacional, os candidatos/partidos/militantes da oposição foram submetidos a repressão, intimidação, violência ou abuso pelo governo, pelo partido do governo ou por seus agentes?

Esclarecimento: Outros tipos de violência civil durante as eleições, mesmo que politicamente motivados, não devem ser considerados quando da resposta desse indicador (serão considerados separadamente em outra pergunta).

Respostas:

0: Sim. A repressão e a intimidação pelo governo ou por seus agentes foi tão intensa que todo o período foi marcado pelo silêncio da oposição.

1: Sim, frequentemente. Houve sistemático, frequente e violento abuso e intimidação da oposição pelo governo ou por seus agentes durante esse período eleitoral.

2: Sim, algum. Houve abusos e intimidação periódicos, não sistemáticos, mas possivelmente coordenados centralmente, da oposição pelo governo ou por seus agentes.

3: Limitado. Houve instâncias de abuso ou intimidação violenta esporádicas da oposição pelo governo ou por seus agentes, em ao menos uma parte do país, e direcionada a apenas uma ou duas unidades locais da oposição.

4: Não. Não houve abuso ou intimidação da oposição pelo governo ou por seus agentes, durante a campanha eleitoral e no dia da eleição.

Fonte: Coppedge et al. (2016b, p. 88).

\footnotetext{
${ }^{6}$ Essa estratégia permite tanto a criação de indicadores de natureza contínua para cada uma das variáveis pesquisadas quanto a reunião desses valores em grupos para reproduzir as categorias que organizavam as perguntas do survey. Por causa disso é possível "categorizar" os dados contínuos indicados nos gráficos aqui apresentados. Neste artigo, os gráficos apresentam os valores obtidos para as variáveis contínuas. Contudo, linhas que dividem o eixo y mostram em quais das categorias originais cada valor se encaixa.
} 
VARIEDADES DA DEMOCRACIA NO BRASIL

$\mathrm{Na}$ categoria seguinte, incluem-se casos e abusos periódicos mas não sistemáticos. As eleições brasileiras da República Velha (1900-1930) e as demais eleições realizadas durante o Regime Militar $(1966,1974,1978)$ recebem essa classificação. Casos com abusos esporádicos e geograficamente circunscritos são incluídos na resposta 3, representando situações em que a intimidação da oposição pelos agentes do governo é limitada. As eleições do período 1950-1962 e as de 1982 são algumas das eleições brasileiras que pontuam nessa categoria. Eleições plenamente livres de intimidação da oposição por parte do governo são classificadas na categoria 4. As eleições brasileiras do período democrático contemporâneo (1986-2014) são exemplos nessa categoria.

A maioria das perguntas no V-Dem, contudo, não são limitadas aos anos eleitorais, tendo sido codificadas de maneira similar à descrita acima para todos os anos em todos os países. O resultado dessa sequência de estratégias de pesquisa é um banco de dados com mais de 400 indicadores sobre diferentes dimensões da democracia para 176 países do mundo no período 1900-2015, incluindo períodos coloniais. É importante notar que os valores observados para um país em determinado ano não são uma medida direta de indicadores objetivos, mas a tradução da percepção que os especialistas têm de cada um dos parâmetros da pesquisa.

Como demonstrado na Figura 1, esses indicadores refinados e desagregados de práticas, instituições e dinâmicas dos regimes políticos são também agregados pelo projeto para formar índices mais complexos, representando conceitos tradicionais da literatura sobre regimes políticos no país. Um exemplo dessa agregação é o índice de eleições limpas, que agrega a questão sobre intimidação da oposição descrita acima a outros indicadores que buscam medir a limpeza e a justeza das eleições em um país em determinado ano (listados na Figura 1). Esse índice é posteriormente agregado a outros índices para formar medidas de conceitos ainda mais complexos (como, no caso, medidas do índice de democracia eleitoral).

Dessa forma, o V-Dem se constitui em uma fonte sem paralelos de informações sobre os sistemas políticos do mundo, potencialmente servindo como recurso para pesquisas longitudinais e comparativas em ciência política. No presente artigo nós apresentamos os dados recolhidos pelo projeto sobre o Brasil.

\section{O V-Dem no Brasil}

Os dados do V-Dem para o Brasil foram produzidos por um time de 28 especialistas que responderam a todas as questões do survey para o país no período 1900-2015. O desenho de pesquisa do V-Dem agrupava as questões em subgrupos ${ }^{7}$ e cada especialista participante do projeto respondeu a todas as questões de ao menos um subgrupo.

\footnotetext{
7 Os subgrupos eram: Sociedade Civil, Liberdades Civis, Deliberação, Eleições, Executivo, Judiciário, Legislativo, Mídia, Igualdade Política, Partidos Políticos, Soberania.
} 
No que tange à produção dos dados, o projeto se empenhou em agregar conhecimento local e internacional sobre os países pesquisados, incorporando pesquisadores nascidos, treinados e empregados tanto dentro de um país quanto fora dele. No caso do Brasil, $71 \%$ dos 28 pesquisadores que responderam ao survey (20 pesquisadores) nasceram no Brasil, sendo que 19 deles ( $68 \%$ do total) moravam no país e foram formados em instituição de ensino superior brasileira. Todos os pesquisadores que codificaram o Brasil têm ao menos um título de pós-graduação. Os pesquisadores não residentes no Brasil foram educados predominantemente nos Estados Unidos e lá residem.

A maior parte dos pesquisadores que colaboraram com o $\mathrm{V}$-Dem para codificar o Brasil atua na academia (20 codificadores), quatro atuam na iniciativa privada e um se encontrava desempregado (há também três codificadores sobre os quais não há informação a respeito da área em que trabalham). Aproximadamente dois terços (18) dos codificadores eram homens e $25 \%$ (sete) eram mulheres ${ }^{8}$, tendo eles em média 40 anos.

Há ainda um grupo adicional de colaboradores - brasileiros e estrangeiros classificados como codificadores laterais, que codificaram vários países do mundo para o ano 2012. Diversos desses codificadores avaliaram o Brasil. Tais codificadores permitiram uma maior precisão na elaboração do modelo de medida que gera os pontos estimados para cada país em cada ano, já que eles forneciam importantes informações sobre a avaliação comparativa dos países.

\section{Democracia eleitoral}

O pré-requisito mais importante para a definição de um regime político como pertencente ao grupo das democracias é a presença das condições resumidas no conceito de poliarquia (Dahl, 1971, 1989). Subdividido em dois domínios principais - participação e contestação -, regimes poliárquicos incluem a presença e a efetividade de mecanismos que permitem que cidadãos interessados nos caminhos da política em um determinado país possam influenciar tais caminhos, eventualmente participar diretamente na condução do governo e do Estado, e fiscalizar e rejeitar o governo de ocasião se assim julgarem necessário (Dahl, 1971).

Nesse sentido, a noção de poliarquia expande - ainda que inserida no mesmo referencial teórico - concepções minimalistas de democracia, incorporando aos tradicionais indicadores associados à existência e à competitividade das eleições indicadores que medem a liberdade e o acesso à informação política, a liberdade de organização da oposição e a liberdade de expressão de cidadãos e grupos no interior de uma sociedade (Teorell et al., 2016).

\footnotetext{
${ }^{8}$ Não há informações para três respondentes.
} 
VARIEDADES DA DEMOCRACIA NO BRASIL

Partindo dessa estrutura teórica, variáveis presentes no V-Dem buscam capturar informações sobre cada uma dessas características em um regime político. Informações que dão conta da medida em que eleições são limpas e decisivas, que delimitam o alcance do sufrágio (medido pela porcentagem da população que tem garantido o direito ao voto) e medem a possibilidade de associação de grupos de oposição tentam medir a dimensão da participação eleitoral em uma democracia. Informações sobre liberdade de expressão individual - inclusive separadas por gênero - e de grupo - como liberdade religiosa - também foram coletadas. Tais informações, em parceria com uma série de dados sobre a liberdade de imprensa, medem os graus de contestação presentes no regime. A combinação dos componentes de participação eleitoral e contestação produz um índice agregado de democracia eleitoral (Teorell et al., 2016).

A Figura 3 apresenta a evolução desse índice para o Brasil entre 1900 e 2015. O gráfico pode ser visto como uma síntese da história política do país, no qual se observam as duas principais tendências que a marcam desde o início do século XX: a alternância entre regimes democráticos e autoritários e o incremento da democracia brasileira a cada nova experiência com esse regime. A primeira dessas tendências é facilmente observável pelos recuos autoritários observados em 1930 e $1964^{9}$, que marcam o início do período de predomínio de Getúlio Vargas sobre a política brasileira e o início da ditadura militar. Cada recuo, contudo, é sucedido por uma nova experiência democrática que supera a experiência anterior ${ }^{10}$.

\footnotetext{
${ }^{9}$ O período autoritário que vai de 1930 a 1945 está destacado em todos os gráficos por um retângulo em cinza. O período da ditadura militar (1964-1985) recebe tratamento semelhante para facilitar a visualização.

10 Todos os gráficos apresentados neste artigo seguem as definições estabelecidas para o projeto nos quais valores mais altos em quaisquer indicadores correspondem a resultados "mais democráticos" enquanto valores mais baixos nos indicadores apontam o oposto. Os gráficos também incluem intervalos de credibilidade ao redor dos pontos estimados. Os intervalos de credibilidade apresentados abrangem um desvio-padrão (68\%) ao redor do ponto estimado e foram calculados a partir do modelo de medida bayesiano de teoria de resposta-item mencionado acima para indicadores, e a partir de análises fatoriais bayesianas para os índices. Figuras com dados para índices têm o eixo $Y$ variando de 0 a 1 . Figuras com dados para indicadores têm o eixo $Y$ variando entre o menor e o maior valor obtidos por qualquer país (incluindo os valores dos intervalos de credibilidade) naquele indicador. Figuras com indicadores incluem linhas que demarcam os intervalos dos valores contínuos compreendidos em cada uma das categorias presentes nas perguntas.
} 
Figura 3

Evolução do índice de democracia eleitoral (1900-2015)

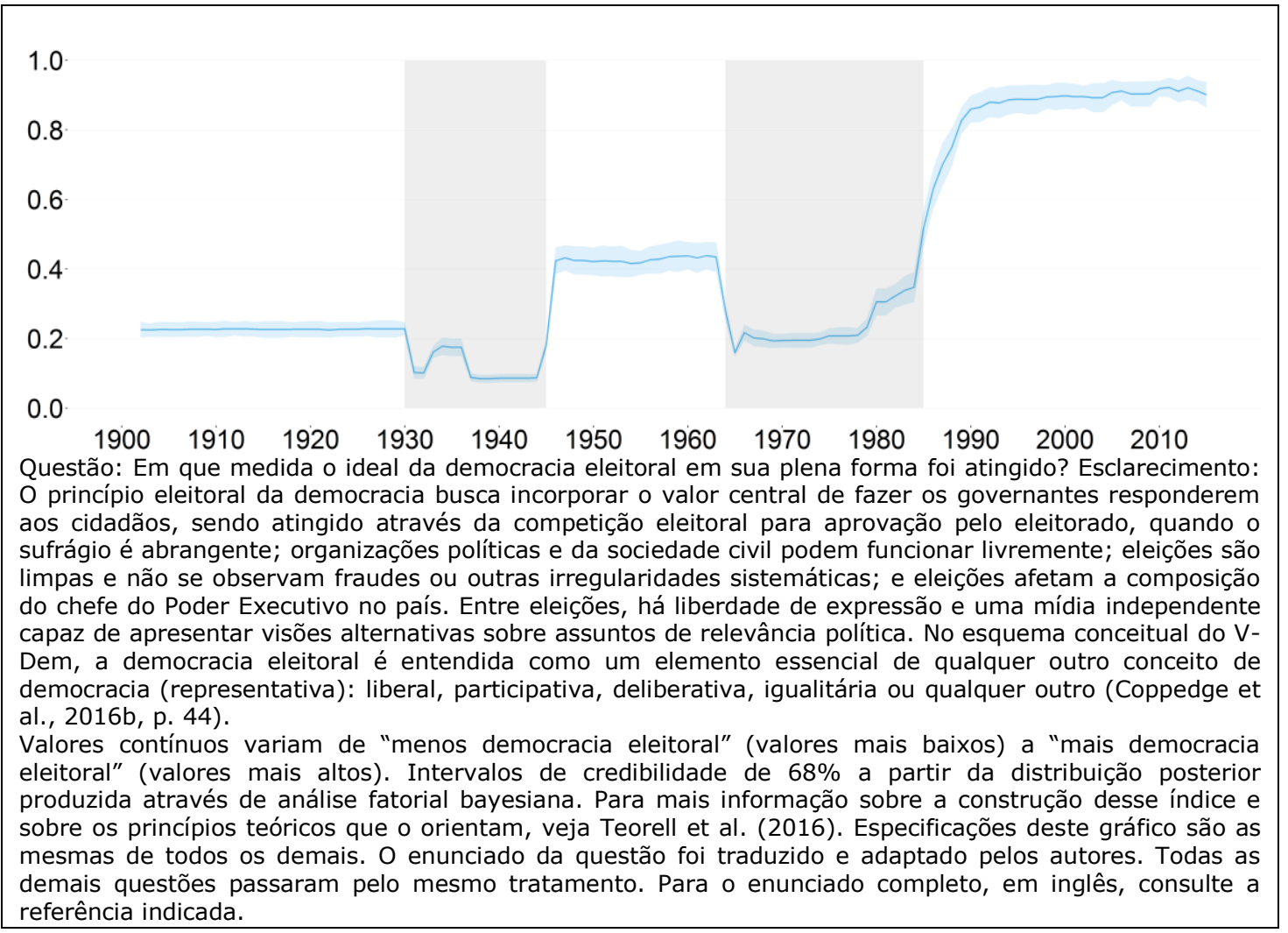

Entre 1889, data da Proclamação da República, e 1930, o Brasil viveu sob um regime político de democracia limitada, no qual tanto a participação quanto a contestação eram reduzidas. Conhecido como República Velha ou Primeira República, o regime era marcado pelo limitado alcance do sufrágio (ainda censitário), pela manutenção de práticas autoritárias por parte do Poder Executivo e por eleições ainda distantes dos padrões de limpeza e competitividade que definem regimes plenamente democráticos (Carone, 1970; Porto, 2002; Ricci e Zulini, 2012). Casos de intimidação eleitoral e fraude eram comuns e a contestação política em nível nacional era praticamente inexistente, dada a predominância dos arranjos intraelites sintetizados na expressão "política dos governadores" (Souza, 1968).

A interrupção do processo constitucional após as eleições de 1930 limitou ainda mais os níveis de democracia observados no país. Getúlio Dorneles Vargas tomou o poder após um golpe que visava impedir a manutenção da chamada política "café com leite", na qual a presidência da República era ocupada alternadamente por membros das elites políticas dos estados de São Paulo e Minas Gerais (Carone, 1973). Com o golpe, o índice de poliarquia no Brasil naquele período diminui subitamente em 1930. Há uma 
VARIEDADES DA DEMOCRACIA NO BRASIL

pequena elevação após os enfrentamentos entre o governo nacional e o estado de São Paulo em 1930, que forçou o governo a recuperar algumas garantias democráticas, consolidadas pela nova Constituição de 1934. Contudo, o "golpe do Estado Novo" novamente causa uma redução do índice de poliarquia. Direitos políticos são suspensos e - Congresso é fechado, fazendo com que o país viva seu período de mais intenso autoritarismo (Sola, 1968).

A retomada da democracia em 1945 é observada no gráfico da Figura 1 com a importante elevação do índice de poliarquia a partir desse ano. Com o fim do Estado Novo, o Brasil vive pela primeira vez sob uma democracia de massas (Skidmore, 1975). O sufrágio foi expandido para homens e mulheres alfabetizados e a competição política se consolidou (Limongi, 2012). Industrialização e urbanização produziram uma sociedade de massas que experimentou importantes transformações, as quais ajudaram a elevar o índice de poliarquia, como a consolidação da Justiça Eleitoral e de uma mídia nacional independente do Estado (Soares, 1973). Isso fez com que a primeira volta na espiral dos regimes brasileiros se completasse: retomada da democracia após o fim do Estado Novo com a expansão dos níveis da poliarquia a partir desse momento em comparação com a primeira experiência democrática no país ${ }^{11}$.

Essa experiência democrática, no entanto, foi abruptamente encerrada por mais um recuo autoritário. Em um contexto internacional marcado pelas tensões da Guerra Fria e a presença de uma onda autoritária no continente, após a qual a maioria dos países sul-americanos observou a emergência de regimes autoritários liderados por militares (Linz e Stepan, 1978), a crescente polarização política no Brasil produziu as condições para a retirada à força do presidente João Goulart do poder (Santos, 1986). A suspensão do regime eleitoral vigente, com a eventual eleição indireta do marechal Humberto Castello Branco para a presidência pelo Congresso, e os limites aos direitos individuais e coletivos de oposição impostos pelos chamados "Atos Institucionais" promulgados pelo regime fizeram cair o índice de poliarquia brasileiro a partir de 1964 .

O índice só voltaria a se recuperar ao final dos anos 1970, com o início da redemocratização. Ainda liderada pelos militares (Kinzo, 2001), a abertura seguiu "lenta, segura e gradual", como a definiu o presidente general Ernesto Geisel em 1973 (Gaspari, 2004), marcada pelo aumento da competitividade das eleições a partir de 1974 e principalmente pela suspensão do AI-5, o principal mecanismo autoritário instaurado pela ditadura brasileira para suspender direitos políticos de cidadãos brasileiros (Lamounier, 1988), em 1978. A Lei de Anistia e a maior liberdade para a organização de partidos políticos, estabelecidas em 1979, também colaboram com a elevação observada ao final dos anos 1980. Tais movimentos podem ser observados pela pequena elevação do índice de poliarquia apresentado na Figura 3 para o período.

Em 1985, Tancredo Neves foi eleito pelo Congresso presidente da República, encerrando os 21 anos de ditadura no Brasil. Neves, um moderado de oposição que

\footnotetext{
${ }^{11}$ Essa nova democracia era, contudo, ainda muito limitada, como explicitado adiante em análises das diferentes dimensões do regime.
} 
conquistou o apoio de importantes setores do governo para encerrar a ditadura contra a "linha-dura" - exemplo típico dos mecanismos de transição bem-sucedidos na região (O’Donnell e Schmitter, 1989) -, não governou (faleceu sem assumir). José Sarney, vicepresidente eleito, governou o país nos primeiros anos da democracia, ao mesmo tempo em que o Congresso preparava a nova Constituição, almejando remover do arcabouço institucional brasileiro o "entulho autoritário" deixado pelo regime anterior (Rocha, 2013). Esses dois momentos - a retomada do governo civil com a eleição de NevesSarney e a promulgação da nova Constituição (1988) - são claros na Figura 3: eles representam o importante incremento no índice de poliarquia brasileiro, levando o país ao seu período de maior democracia em sua história. A espiral deu mais uma volta. 0 Brasil retornava à democracia, agora com mais democracia.

Como mencionado acima, um dos princípios que guiam o $\mathrm{V}$-Dem é a possibilidade de desagregar os índices mais complexos em indicadores mais precisos das características dos regimes políticos. A Figura 4 desagrega o índice de democracia eleitoral em seus cinco subíndices e indicadores: um índice que mede a limpeza e a justiça das eleições, um índice que mede a liberdade de associação, um índice de liberdade de expressão, um indicador que mede a extensão do sufrágio e um indicador que mostra se o chefe do Poder Executivo foi eleito ou não. Com isso, se observa como essa desagregação nos ajuda a obter uma interpretação mais precisa das dinâmicas experimentadas pelo país no período. Tomemos o período da ditadura militar como exemplo. Os índices de liberdade de expressão e de liberdade de associação encontramse no grupo dos valores mínimos observados entre 1964 e o início da transição (atingindo o valor mais baixo entre 1968 e 1978, enquanto vigorou o AI-5). Tais índices sofrem uma queda claramente mais brusca que o índice que mede a limpeza e a justiça das eleições após 1964, algo esperado à luz daquilo que sabemos sobre o regime. Por um lado, ainda que importantes limites à competição eleitoral tenham sido impostos, as eleições locais e estaduais realizadas durante a ditadura não foram marcadas por casos extremos de fraude ou violência. Por outro, o direito de formar organizações políticas e civis para se opor ao governo ou o direito de se expressar livremente contra o governo foram severamente limitados durante grande parte da ditadura, inclusive por meio de repressão violenta, prisões, tortura e assassinatos. Ainda, a Figura 4 inclui as duas dimensões institucionais mais básicas da democracia eleitoral, a saber: a existência de um regime em que o chefe de governo é eleito (direta ou indiretamente) ${ }^{12}$ e a extensão do sufrágio. É possível perceber que a principal mudança historicamente observável na Figura 4 é que cada vez mais brasileiros conquistaram o direito ao voto, incluindo a importante expansão em 1932, quando o voto foi estendido às mulheres alfabetizadas, e, depois, a expansão que segue à promulgação da Constituição de 1988, com a extensão do sufrágio aos analfabetos. No intervalo entre esses dois momentos, o crescimento é

\footnotetext{
${ }^{12}$ Como o marechal Castello Branco foi eleito presidente pelo Congresso Nacional após o golpe militar em 1964, os dados no último painel da Figura 4 não apresentam nenhuma alteração após 1964.
} 
VARIEDADES DA DEMOCRACIA NO BRASIL

mais gradual, seguindo a longa diminuição do número de analfabetos através dos anos (Nicolau, 2012).

\section{Figura 4 \\ Evolução dos índices que compõem o índice de democracia eleitoral (1900-2015)}

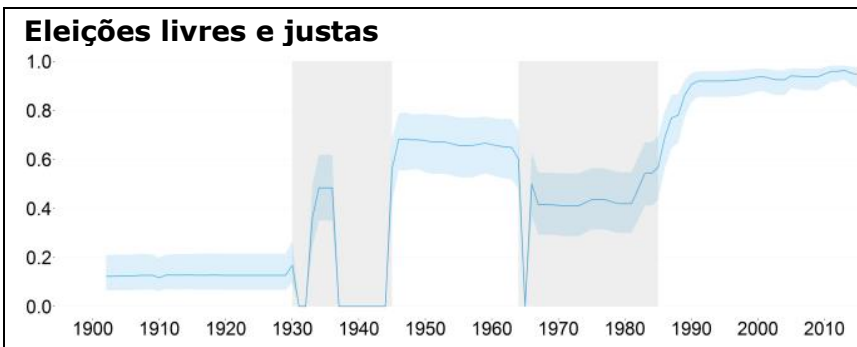

Questão: Em que medida as eleições são livres e justas? Esclarecimento: "livres e justas" conotam a ausência de fraudes nos registros, de irregularidades sistemáticas, de intimidação da oposição pelo governo, de compra de votos e de violência durante as eleições (Coppedge et al., 2016b, p. 54).

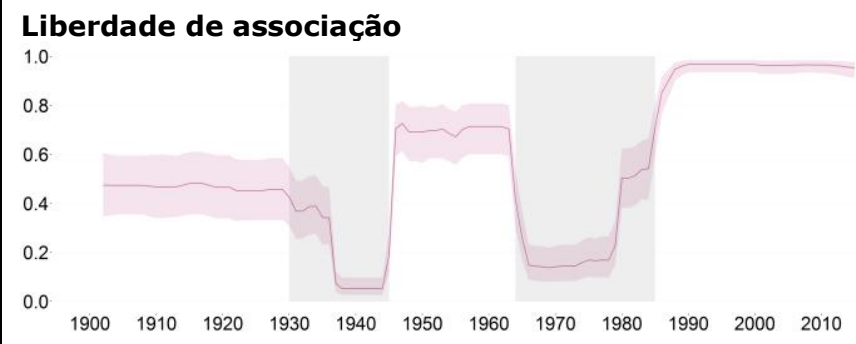

Questão: Em que medida são os partidos, incluindo os partidos de oposição, livres para se formar e participar das eleições, e em que medida são as organizações da sociedade civil capazes de se formar e operar livremente? (Coppedge et al., 2016b, p. 51-52).

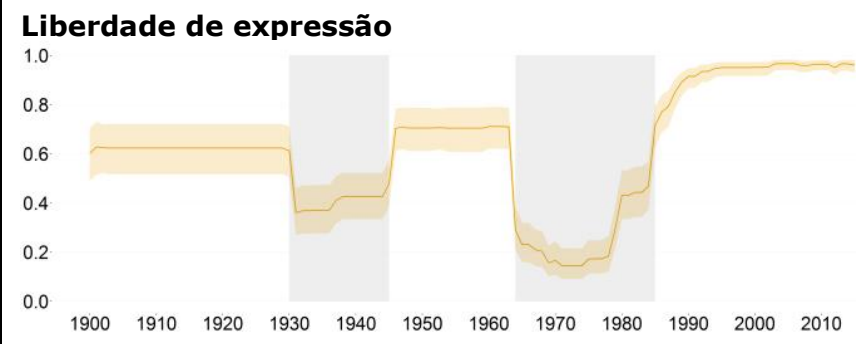

Questão: Em que medida o governo respeita a liberdade da imprensa, a liberdade das pessoas para discutir assuntos políticos em casa e na esfera pública, bem como a liberdade de expressão acadêmica e cultural? (Coppedge et al., 2016b, p. 52). 


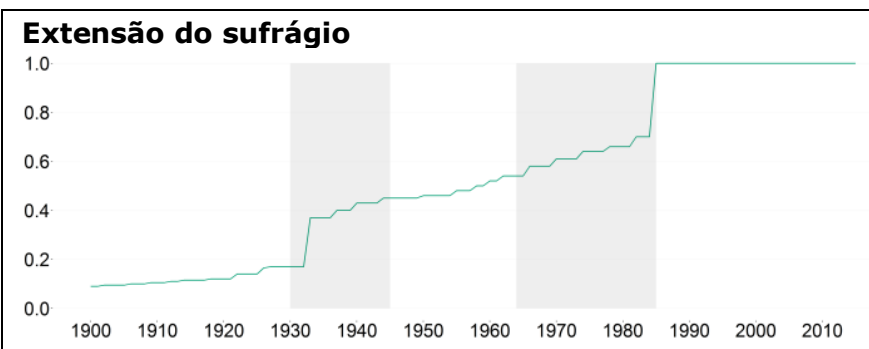

Questão: Qual a parcela dos cidadãos adultos que tem o direito legal de votar em eleições? Esclarecimento: Essa questão não leva em consideração restrições baseadas em idade, residência, ter sido condenado por um crime, ou ser legalmente incompetente (apenas restrições de jure, não restrições de facto) (Coppedge et al., 2016b, p. 51-52).

\section{Executivo eleito}

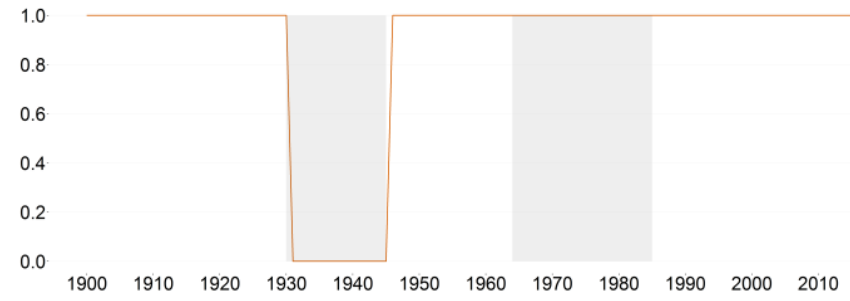

Questão: É o chefe do Executivo escolhido através de eleições populares (direta ou indiretamente)? Esclarecimento: Esse índice tenta medir se o chefe do Executivo é eleito, diretamente através de eleições populares ou indiretamente através de uma legislatura eleita por voto popular que aponta o chefe do Executivo. Resposta: 0. Não. 1. Sim (Coppedge et al., 2016b, p. 54).

Novamente é possível desagregar os índices e observar os indicadores que fazem parte dos subíndices do índice de democracia eleitoral. A Figura 5 contém informações sobre a presença de eleições livres e limpas. A observação dos dados desses gráficos oferece uma leitura interessante da história eleitoral brasileira. Primeiramente, a figura mostra como episódios de violência durante as eleições têm sido relativamente raros (valores mais altos no gráfico representam menos violência eleitoral). Com exceção do período da República Velha e do pico de violência nas eleições de 1932, em que as disputas entre integralistas e comunistas foram as mais violentas da história brasileira, o indicador aponta que as eleições brasileiras pertencem à categoria máxima na escala dessa variável para o V-Dem, na qual se lê "a eleição transcorreu em paz" (Coppedge et al., 2016b, p. 89) $)^{13}$.

\footnotetext{
${ }^{13}$ Indicadores que medem características de eleições, como violência eleitoral e todos os demais na Figura 5 , são medidos apenas nos anos eleitorais. Em anos não eleitorais, nós repetimos os valores do último ano eleitoral, desde que não tenha havido nenhuma interrupção do calendário eleitoral desde então.
} 
Figura 5

Evolução dos indicadores que compõem o índice de eleições livres e justas

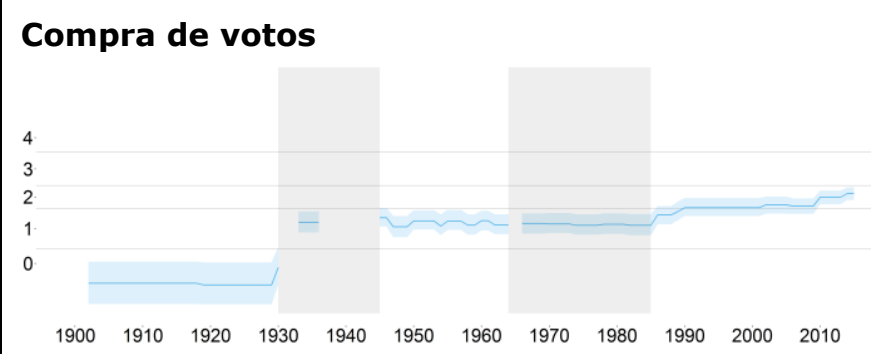

Questão: Nessa eleição nacional, houve evidência de compra de votos? Respostas: 0 . Sim. Sistemática e generalizada. 1. Alguma. Comum em partes do país ou por alguns partidos. 2. Restrita. Houve distribuição de recursos, mas com pouco efeito sobre os eleitores. 3. Quase nenhuma. Utilização limitada a poucos candidatos e regiões. 4. Não houve evidência de compra de votos (Coppedge et al., 2016b, p. 87).

\section{Violência eleitoral}

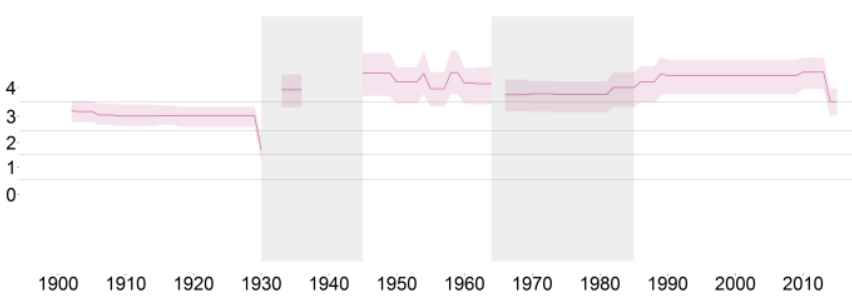

Questão: Nessa eleição nacional, foram a campanha, o dia da eleição ou o período póseleitoral livres de violência? Respostas: 0. Não. Houve violência generalizada. 1. Houve muita violência, mas limitada. 2. Alguma, em pequenas partes do país ou por curtos períodos de tempo. 3. Quase completamente, com violência muito limitada. 4. Sim. Eleição transcorreu em paz (Coppedge et al., 2016b, p. 89).

\section{Intimidação da oposição}

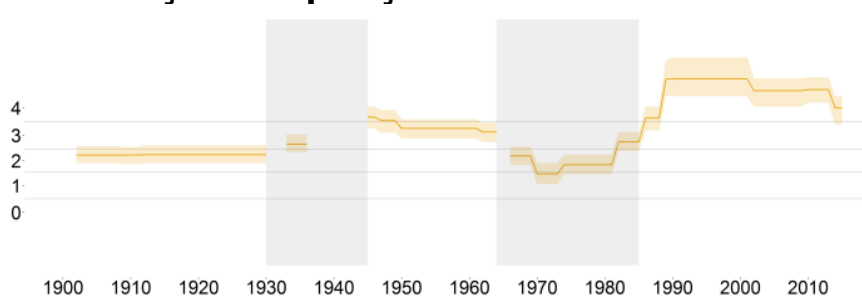

Questão: Nessa eleição nacional, foi a oposição sujeitada a repressão, intimidação, violências ou abusos por parte do governo ou seus agentes? Respostas: 0. Sim, a todo momento. 1. Frequentemente. 2. Periódica, mas não sistematicamente. 3. De maneira muito restrita. 4. Não houve intimidação (Coppedge et al., 2016b, p. 88-89). 


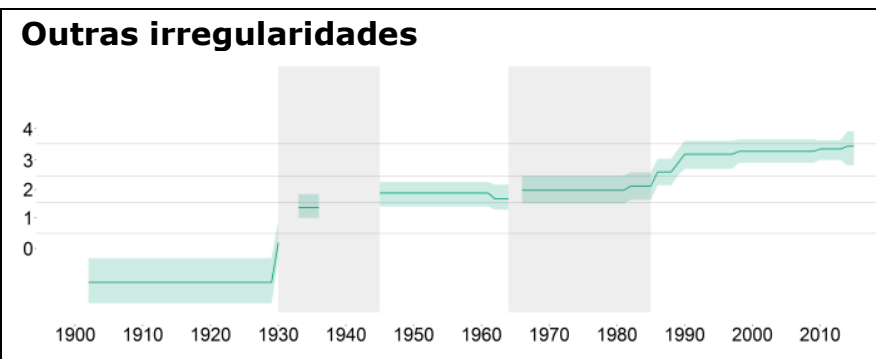

Questão: Nessa eleição nacional, houve evidência de outras irregularidades durante as eleições? Respostas: 0. Sim. Sistemáticas e generalizadas. 1. Alguma. Comum em partes do país. 2. Esporádicas. Houve irregularidades, mas não é claro se foram intencionais ou direcionadas. 3. Quase nenhuma. Provavelmente não intencionais. 4. Não houve evidência de outras irregularidades (Coppedge et al., 2016b, p. 87-88).

\section{Eleições livres e justas}

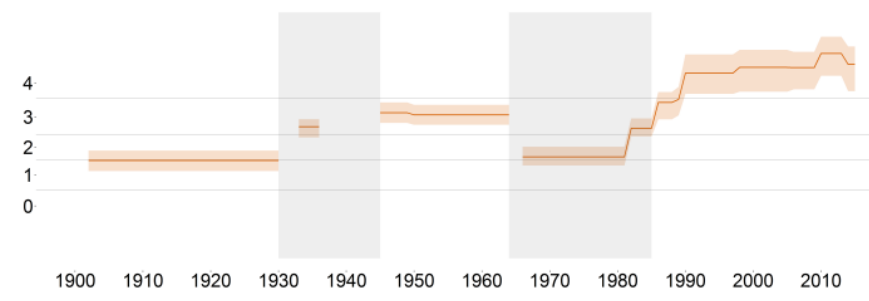

Questão: Levando em consideração todos os aspectos dos períodos pré e pós-eleitorais, e do dia da eleição, você consideraria essas eleições livres e justas? Respostas: 0. Não, de maneira nenhuma. 1. Não completamente. 2. Mais ou menos. 3. Sim, em sua maior parte. 4. Sim. (Coppedge et al., 2016b, p. 96).

Essa dinâmica é diferente da observada, por exemplo, para o indicador que mede a presença de intimidação governamental da oposição. Esse indicador demonstra os limites da competitividade eleitoral no período da República Velha, classificada como tão baixa quanto durante a ditadura militar, indicando - de acordo com as categorias do VDem - a existência "de perseguição periódica mas não sistemática da oposição" (Coppedge et al., 2016b, p. 89) por parte das forças do governo. Ele também demonstra a importante evolução da democracia brasileira no período recente, quando pela primeira vez o indicador se localiza na categoria máxima, em que se aponta a ausência de perseguição da oposição por parte do governo durante as eleições.

A Figura 5 também indica o principal problema contemporâneo para a limpeza das eleições brasileiras: a persistência de ocasiões em que a compra de votos é observada. No indicador de compra de votos, as eleições brasileiras nunca cruzam a fronteira da categoria máxima. Há, contudo, uma trajetória de importante melhoramento: na República Velha, os resultados brasileiros se encontravam na categoria mínima, definida como a existência de compra de votos "sistemática, comum, em todo o território nacional, realizada por todos os partidos e candidatos" (Coppedge et al., 2016b, p. 87). Como a literatura tem apontado, essa situação melhora 
VARIEDADES DA DEMOCRACIA NO BRASIL

substancialmente com a lei eleitoral de 1932 (Ricci e Zulini, 2014). Os dados do V-Dem mostram que os codificadores consideraram que nesse contexto a compra de voto era "não sistemática, mas comum" (Coppedge et al., 2016b, p. 87). Tal situação permanece praticamente inalterada por muitos anos, pelo menos até as importantes transformações observadas no período democrático contemporâneo e após a Constituição de 1988. Esse incremento não eliminou a compra de votos, mas a transformou, tornando-a menos comum e resultado de uma interação diferenciada entre eleitores e candidatos, na qual "dinheiros e prendas foram distribuídos, mas essas práticas resultam mais do cumprimento de expectativas e menos da compra real de votos e participação" (2016b, p. 87).

O indicador que mede o nível em que codificadores consideraram eleições livres e justas - desenhado justamente para englobar as várias perspectivas relacionadas ao conceito de "free and fair election" - sintetiza as tendências acima mencionadas: os menores valores são observados durante a República Velha e a Ditadura Militar; o período democrático recente obteve valores bastante elevados, dentro da categoria máxima definida pelo projeto.

A desagregação dos demais componentes da dimensão eleitoral da democracia brasileira (não apresentada) mostra séries históricas alinhadas à dinâmica geral dos regimes políticos no Brasil, com decréscimos significativos durante as duas experiências ditatoriais brasileiras, e subsequentes aumentos com o retorno da democracia. Mais especificamente, contudo, é interessante notar como no período democrático contemporâneo os resultados para todos os indicadores se encontram na categoria máxima, reforçando a impressão positiva sobre o desenvolvimento da democracia eleitoral brasileira.

\section{Outras dimensões da democracia brasileira}

Além da dimensão eleitoral da democracia, na qual o Brasil observou importantes transformações ao longo dos últimos 115 anos, o V-Dem também contém índices e indicadores que medem outras quatro dimensões da democracia brasileira. Nesta seção nós discutimos essas dimensões: o componente liberal da democracia, o componente participativo, o componente deliberativo e o componente igualitário. Aliados com a dimensão eleitoral da democracia brasileira discutida anteriormente, eles oferecem um panorama importante dos principais elementos que historicamente compõem o regime político brasileiro.

A Figura 6 apresenta a evolução histórica desses quatro componentes. A figura demonstra como as diferentes dimensões da democracia são relativamente independentes umas das outras. Enquanto todas elas seguem movimentos semelhantes, com incrementos e regressões que acompanham as idas e vindas entre democracia e autoritarismo, elas também são diferenciadas o suficiente em algumas de suas particularidades. 
Figura 6

\section{Evolução dos demais componentes da democracia}

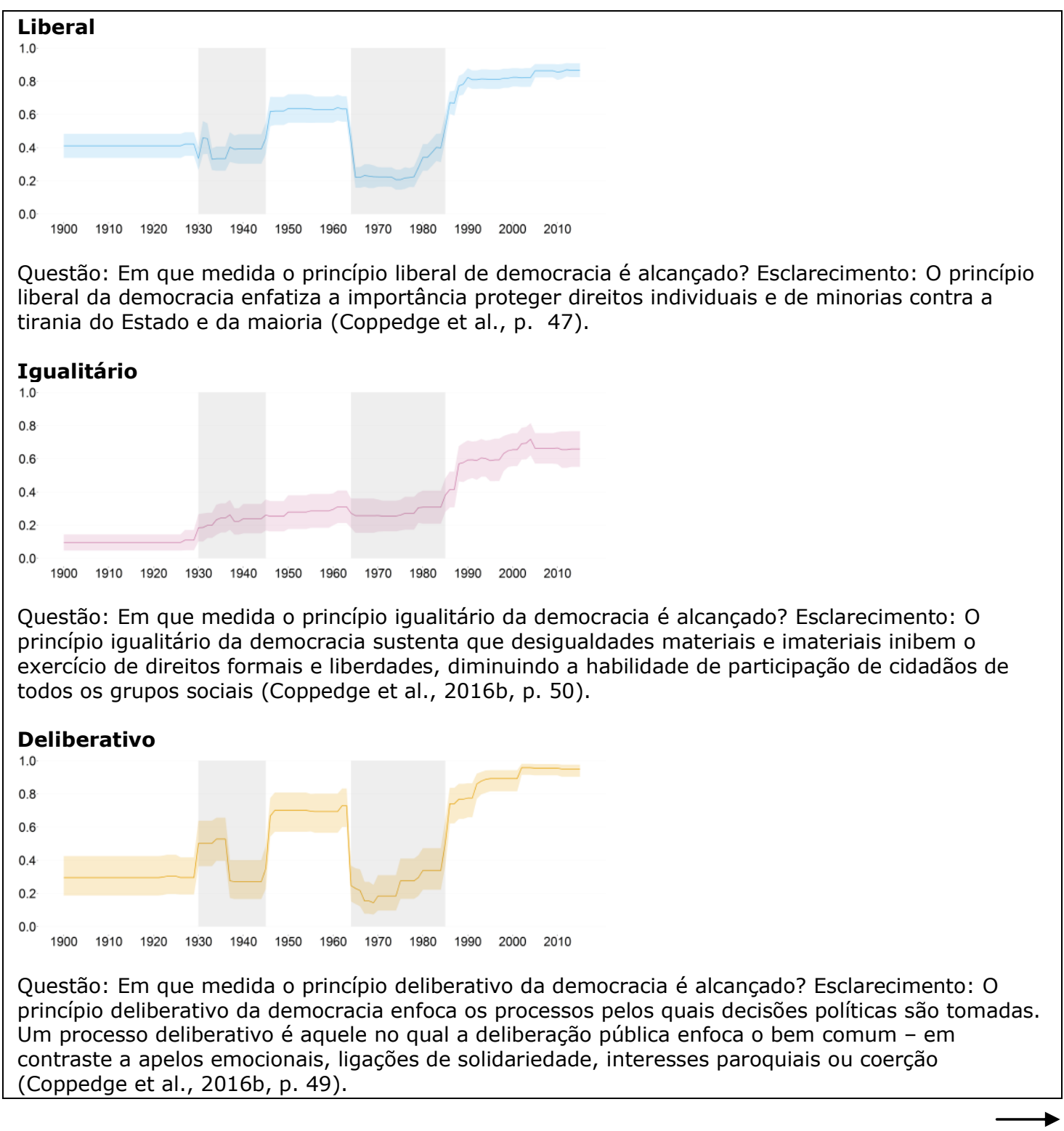


VARIEDADES DA DEMOCRACIA NO BRASIL

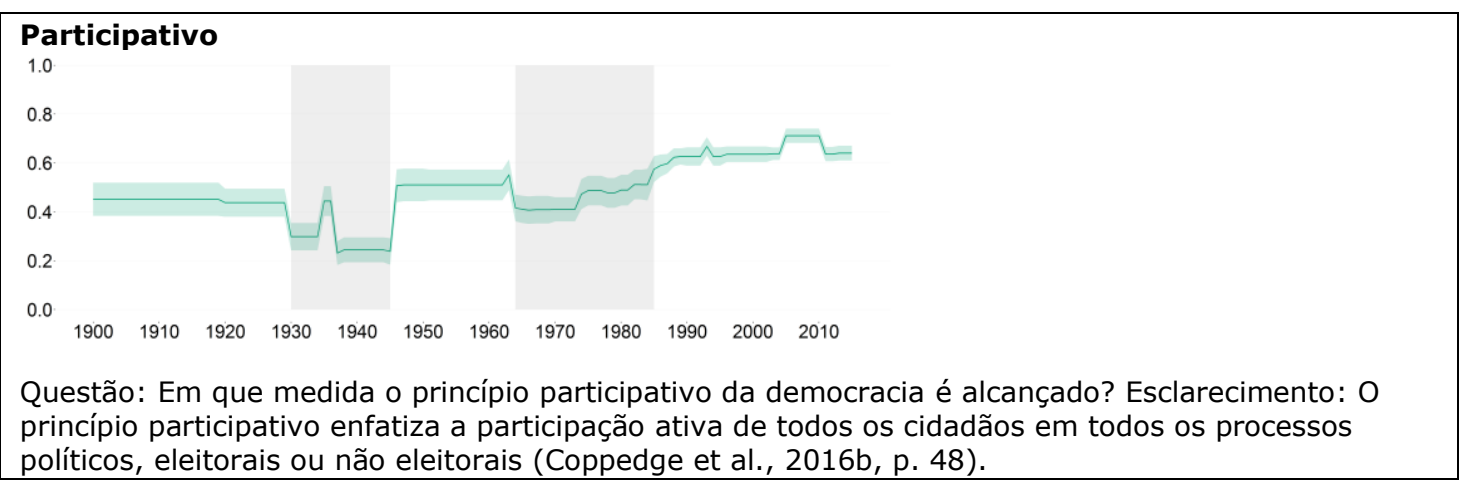

O componente liberal segue a importante tradição da literatura sobre os regimes políticos que enfoca os elementos institucionais e os direitos historicamente associados com a democracia (Dahl, 1989; Held, 1987; Mill, 1964, cap. 3). Em síntese, ele mede os limites da atuação do Estado, a primazia da lei e a garantia dos direitos individuais. Ele é composto de três subíndices, que, por sua vez, incluem diferentes indicadores mais específicos que medem os componentes analisados. Tais três índices, em específico, medem a capacidade que os poderes Judiciário e Legislativo têm para controlar o Poder Executivo e o nível de igualdade diante da lei entre os cidadãos.

A observação da Figura 7, que apresenta os resultados de cada um desses subíndices, mostra que na história dos regimes políticos brasileiros as regressões autoritárias se fizeram muito mais às custas da diminuição da capacidade do Legislativo em controlar o Executivo que às custas do Judiciário. Isso obviamente não significa que os dados não apontem a diminuição da capacidade do Judiciário em limitar o Executivo nos contextos autoritários experimentados pelo Brasil, mas reforça a impressão de que as experiências autoritárias no Brasil tiveram importantes limites, fechando os canais de pressão popular via Legislativo, mas não impedindo a manutenção de certas dinâmicas de controle internas ao Estado brasileiro.

Figura 7

\section{Evolução dos índices que compõem o componente liberal}

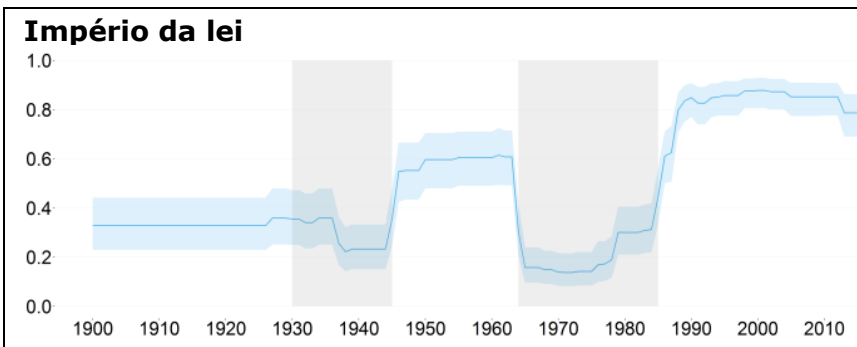

Questão: Em que medida as leis são transparentes e rigorosamente aplicadas, a administração pública é imparcial, e em que medida os cidadãos gozam de acesso à justiça, têm garantido o direito de propriedade, estão protegidos contra o trabalho forçado, têm liberdade de movimento, integridade física e liberdade de religião (Coppedge et al., 2016b, p. 55). 


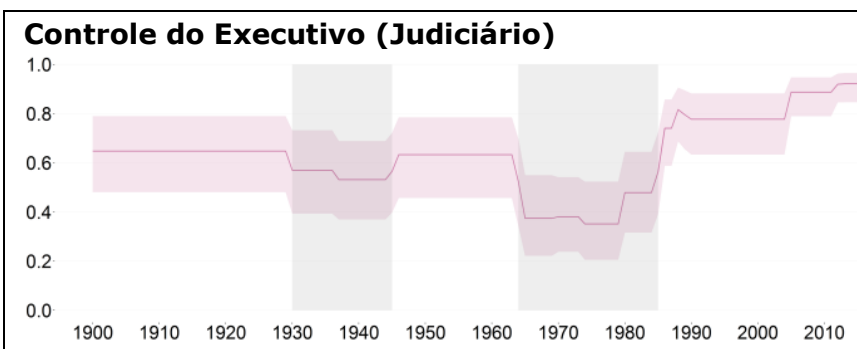

Questão: Em que medida o Executivo respeita a Constituição e as decisões do Judiciário, e em que medida é o Judiciário capaz de agir independentemente (Coppedge et al., 2016b, p. 56).

\section{Controle do Executivo (Legislativo)}

1.0

0.8

0.6

0.4

0.2

$\begin{array}{lllllllllllll}0.0 & 1900 & 1910 & 1920 & 1930 & 1940 & 1950 & 1960 & 1970 & 1980 & 1990 & 2000 & 2010\end{array}$

Questão: Em que medida o Legislativo e as agências governamentais independentes são capazes de questionar, investigar e fiscalizar o Executivo (Coppedge et al., 2016b, p. 56).

Comportamento semelhante é observado no índice que mede a garantia das liberdades individuais (Estado de Direito). O índice recua para valores associados com contextos menos democráticos nos períodos autoritários e melhora ao final de tais regimes. Tal índice acompanha também a tendência geral observada para a democracia brasileira: a cada nova experiência democrática o Brasil se tornou "mais democrático" que na experiência anterior.

Outro componente da democracia estudado é o deliberativo (Figura 8). Sua inspiração vem também de textos clássicos da literatura em teoria política, particularmente aqueles que assumem que a democracia se faz não apenas da agregação de interesses individuais, mas também da presença de um ambiente propício à deliberação anterior às decisões. Nesse sentido, o processo deliberativo é aquele no qual as discussões se orientam pelo "bem comum", ao invés de respeitarem exclusivamente interesses individuais e paroquiais (Dryzek, 2010). De maneira semelhante ao componente liberal (Figura 7), o componente deliberativo sofre mudanças drásticas a cada mudança de regime no Brasil. Em contextos autoritários os valores desse índice decrescem substancialmente, e se recuperam de maneira igualmente forte após a redemocratização ${ }^{14}$. Nesse caso também, o período atual obtém os maiores valores da

${ }^{14}$ É interessante notar, contudo, que os indicadores que compõem o componente deliberativo sofrem uma elevação após o fim da República Velha, decaindo apenas após o golpe do Estado Novo em 1937. Esse curto período de tempo (1930-1937) foi marcado por intensa mobilização e organização política, o que elevou os valores observados. 
VARIEDADES DA DEMOCRACIA NO BRASIL

história política brasileira desde 1900, reforçando a imagem positiva da democracia brasileira contemporânea oferecida pelos dados do V-Dem.

Figura 8

Evolução dos indicadores do componente deliberativo

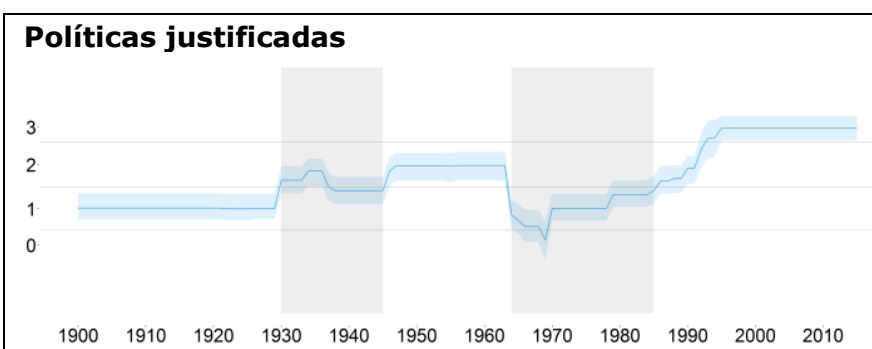

Questão: Quando mudanças importantes nas políticas públicas são consideradas, em que medida as elites políticas dão justificativas de suas posições ao público? Respostas: 0. Nunca. 1. Elites até dão justificativas, mas estas são normalmente ilógicas ou parciais. 2. Elites oferecem apenas uma simples justificativa. 3. Elites oferecem várias e complexas justificativas (Coppedge et al., 2016b, p. 192).

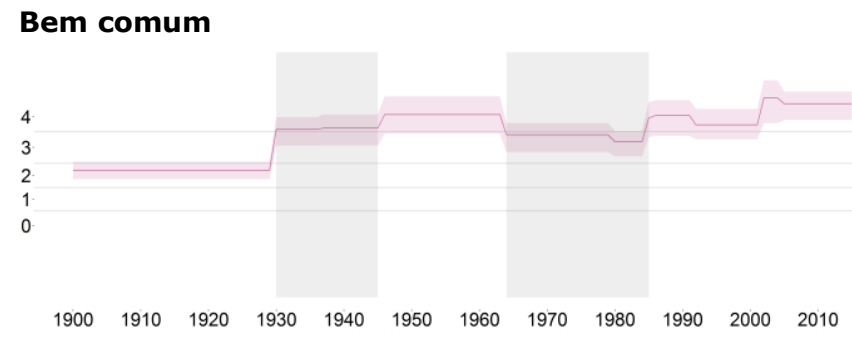

Questão: Quando mudanças importantes nas políticas públicas são consideradas, em que medida as elites políticas justificam suas posições à luz do bem comum? Respostas: 0. Nunca. 1. Justificativas são normalmente limitadas a alguns grupos ou organizações. 2. Justificativas, em sua maior parte, misturam bem comum e interesses particularistas. 3. Justificativas misturam o bem comum ao interesse de alguns grupos. 4. Justificativa, são normalmente baseadas no bem comum (Coppedge et al., 2016b, p. 193). 


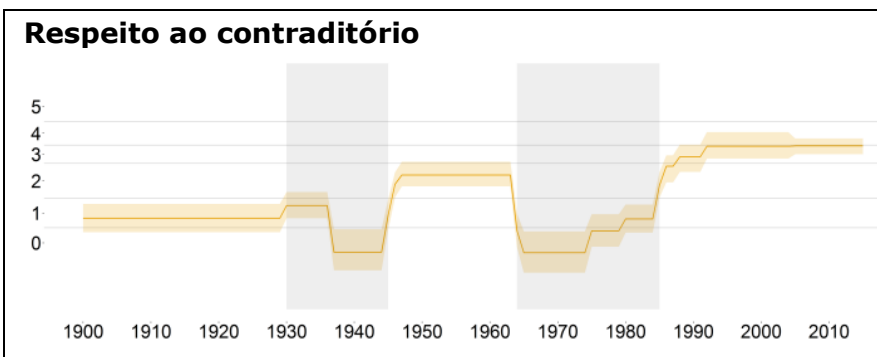

Questão: Quando mudanças importantes nas políticas públicas são consideradas, em que medida as elites políticas reconhecem e respeitam argumentos contrários? Respostas: 0. Não respeitam, e argumentos contrários são punidos. 1. Argumentos contrários são permitidos, mas ignorados. 2. Argumentos são permitidos, mas rejeitados publicamente pelas elites políticas. 3. Elites ouvem argumentos contrários, sem julgar seu valor. 4. Elites ouvem e valorizam argumentos contrários, ainda que não os adotem. 5. Elites ouvem, valorizam, e adotam as posições contrárias às suas (Coppedge et al., 2016b, p. 192).

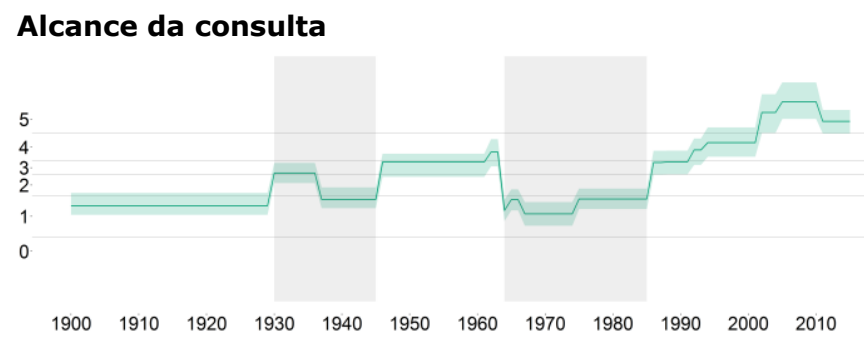

Questão: Quando mudanças importantes nas políticas públicas são consideradas, quão amplo é o alcance da consulta sobre as mudanças no nível das elites? Respostas: 0. Não há consulta. 1. Consulta é mínima. Só o círculo de elites mais próximo do governante. 2. Consulta inclui um grupo amplo de seguidores do governante. 3. Consulta inclui aliados do governo e elites na oposição. 4. Consulta inclui aliados e oposição, inclusive alguns representantes de sindicatos. 5. Consulta inclui todas as elites (Coppedge et al., 2016b, p. 194).

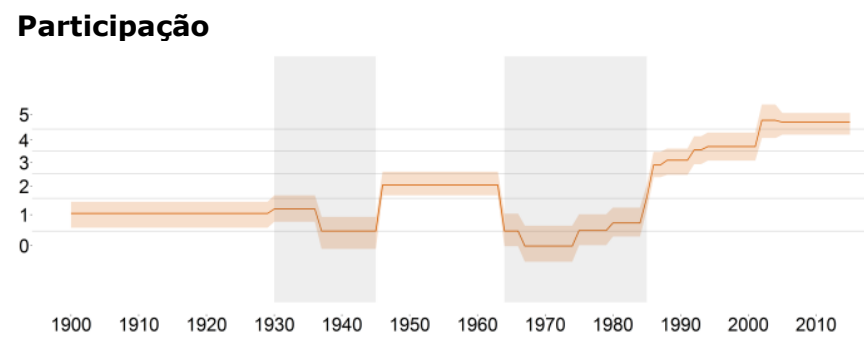

Questão: Quando mudanças importantes nas políticas públicas são consideradas, quão amplas e independentes são as deliberações públicas? 0. Deliberações públicas não são permitidas. 1. Alguma deliberação é permitida, mas o público em geral é alheio às discussões. 2. Deliberação existe e é incentivada, mas apenas um pequeno grupo participa. 3. Deliberação existe e é incentivada, um grupo relativamente amplo participa, mas de maneira diferenciada de acordo com o tema. 4. Deliberação de base é comum e constante. O público debate as questões públicas em múltiplos espaços (Coppedge et al., 2016b, p. 195).

Analisando esse índice de maneira semelhante ao anterior - observando dados para os indicadores individuais nos quais o Brasil se sai historicamente melhor e pior 
VARIEDADES DA DEMOCRACIA NO BRASIL

(Figura 8) - duas importantes dimensões das características dos regimes brasileiros se destacam. Por um lado, o indicador que descreve em que medida a deliberação esteve voltada para o bem comum tem sempre apresentado resultados elevados, tendo historicamente se posicionado muito próximo da categoria máxima - atingindo-a na democracia contemporânea. Os recuos durante os contextos autoritários não foram tão drásticos quanto os observados em outros indicadores. Tal comportamento não é inesperado: diferentemente de regimes personalistas e cleptocráticos que tendem a registrar valores bastante baixos nessa medida, os governos autoritários brasileiros foram fortemente associados com a atuação da burocracia estatal e suas ideias de promoção do desenvolvimento nacional, algo mais próximo da noção de bem comum que aquela que se observa em regimes autoritários de outros tipos. Os indicadores nos quais os resultados brasileiros se saem pior dentre aqueles que compõem o componente deliberativo são os que medem o respeito geral pelo contraditório e a intensidade da participação popular no processo decisório. Novamente, não é surpresa que em um país que tenha experimentado regimes autoritários tais indicadores apresentem consistentemente resultados ruins, dado que esses indicadores tendem a sofrer mais quando da restrição das liberdades individuais e do insulamento dos formuladores da política pública das pressões populares, geralmente canalizadas por lideranças políticas eleitas. No período atual, contudo, esse indicador obtém valores dentro da categoria máxima.

O terceiro componente selecionado para discussão é o componente participativo (Figura 9). Discussões sobre esse componente da democracia estão normalmente orientadas por referenciais teóricos que tomam a participação eleitoral como insuficiente para a plena realização da democracia. Buscando expandir o princípio de delegação de autoridade que embasa o governo representativo, proponentes de formas mais participativas de democracia enfatizam a participação direta de cidadãos e de grupos organizados (sociedade civil) nos processos políticos, sejam eles eleitorais ou não eleitorais (Macpherson, 1977; Pateman, 1970). A análise da evolução histórica mostra como também nesse componente estão capturadas as dinâmicas dos regimes políticos brasileiros, com uma sucessão de altos e baixos simultânea às mudanças entre democracia e autoritarismo, ainda que em menor intensidade que os dois índices discutidos anteriormente. Retomando a Figura 6, percebe-se como, em comparação com os demais componentes e com o índice de democracia eleitoral, a democracia brasileira historicamente "fica devendo" em termos de seu componente participativo. Enquanto nos demais componentes/índices os resultados contemporâneos encontram-se na categoria máxima nos dados do V-Dem ou se aproximam dela, o desempenho do índice que mede o componente participativo apresenta-se apenas como intermediário ${ }^{15}$.

\footnotetext{
${ }^{15}$ É importante notar, contudo, que são muito poucos os casos de países que obtêm resultados elevados nessa categoria. O predomínio do "governo representativo" sobre formas diretas de participação é um traço comum dos regimes políticos nos séculos XX e XXI, o que tende a minimizar o impacto de formas participativas de democracia.
} 
Figura 9

Evolução dos índices do componente participativo

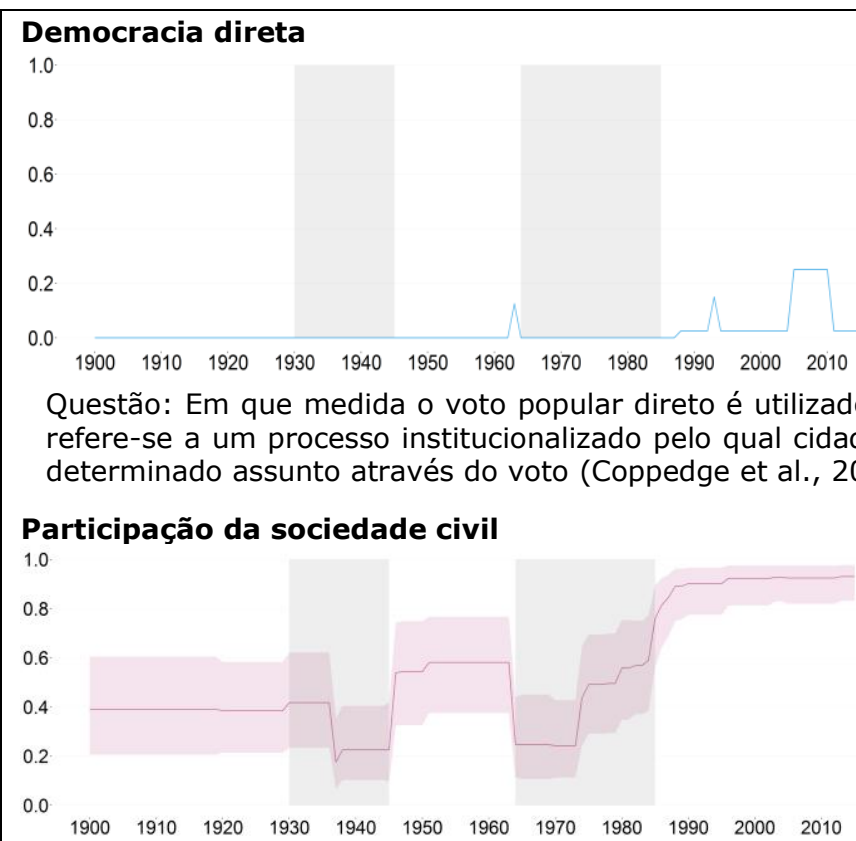

Questão: As organizações da sociedade civil são rotineiramente consultadas pelos elaboradores de políticas públicas? Qual o grau de envolvimento do povo nas organizações da sociedade civil? São as mulheres proibidas de participar dessas organizações? São os candidatos escolhidos de forma centralizada ou descentralizada? (Coppedge et al., 2016b, 56-57).

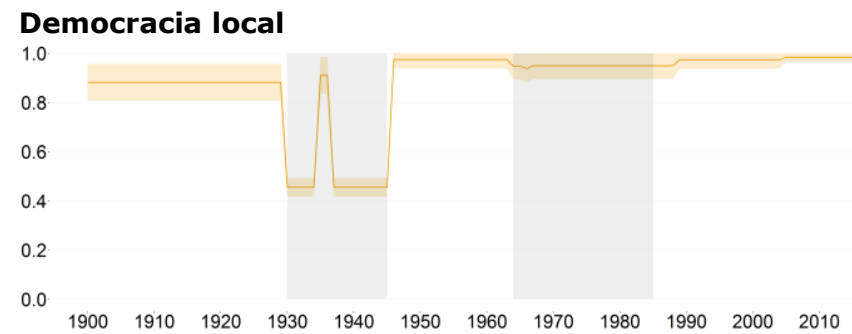

Questão: Existem governos locais eleitos e, nesse caso, em que medida eles conseguem operar sem a interferência de órgãos não eleitos? Esclarecimento: O valor mínimo é destinado a países sem governos locais eleitos. Valores intermediários são para países com governos locais eleitos, mas sem autonomia. Valores altos são para países em que os governos locais são eleitos e autônomos (Coppedge et al.,2016b, p. 58). 


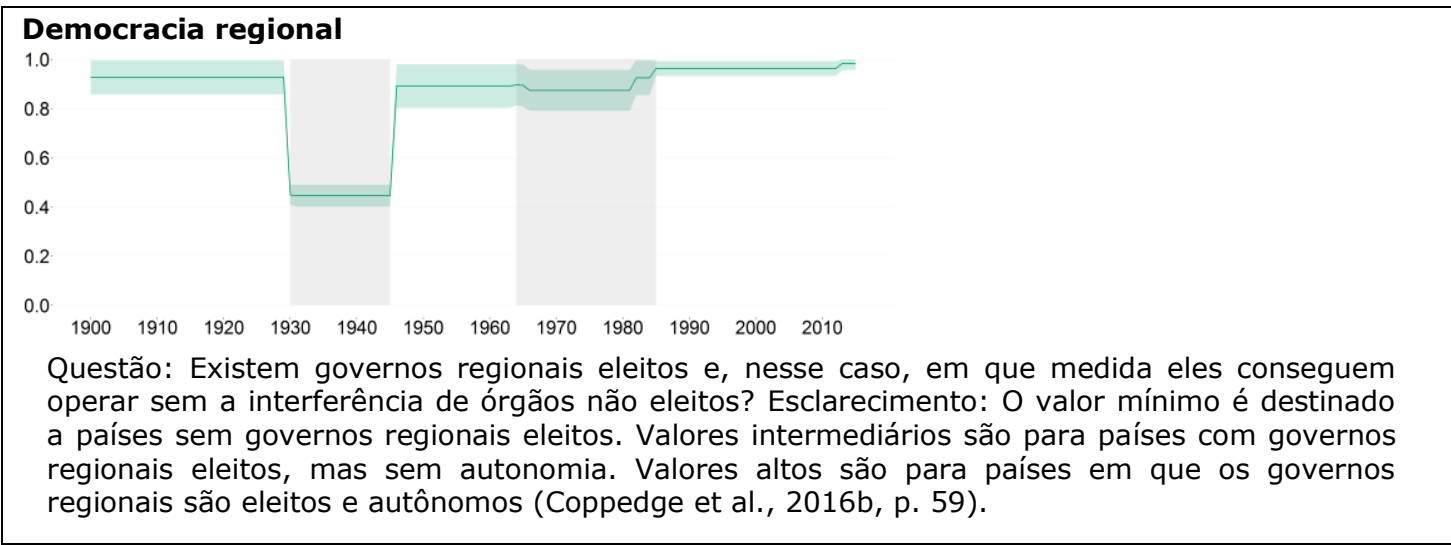

É interessante notar ainda dois importantes pontos que tocam nesse componente participativo (Figura 9). O primeiro é que, a despeito das experiências bem-sucedidas de participação no nível local que marcam alguns contextos brasileiros, essas experiências participativas ainda não se espalharam no território nem ascenderam à estrutura federativa brasileira ao ponto de produzir um incremento substantivo do componente participativo da democracia brasileira. Uma evidência importante nesse sentido é o fato de que é justamente durante o governo do presidente Luiz Inácio Lula da Silva (20032010) que o índice alcança seus maiores valores, recuando para valores semelhantes aos observados anteriormente durante o governo de Dilma Rousseff. Nós interpretamos que essa mudança seja uma expressão da importante experiência que as Conferências Nacionais - mecanismos federais de participação da sociedade civil na elaboração de políticas públicas (Avritzer, 2012) - tiveram para o componente participativo durante aquele período. A suspensão da experiência das Conferências a partir de 2011 pode ser a explicação para o recuo observado ao fim do governo Lula.

O último dos componentes que apresentam novas dimensões da democracia brasileira aqui analisado é o igualitário. Mais do que preocupar-se com regras e procedimentos, o componente igualitário da democracia enfoca em que medida a distribuição de poder político se dá de forma igualitária, e em que medida a igualdade em um sentido mais amplo entre os cidadãos é promovida. Tal perspectiva se ampara na interpretação de que a concessão de direitos políticos não é suficiente para a plena cidadania, assumindo que cidadãos diferentes (em termos de cor, religião, classe social) devem ter capacidade semelhante de ditar as políticas públicas e que, caso tal capacidade não esteja dada, cabe ao Estado promover políticas que garantam a dimensão igualitária da democracia (Dahl, 1982). Na evolução histórica desse índice (Figura 6) é interessante notar como há pouca variação no período 1930-1988. Após um primeiro incremento ao final da República Velha, o índice que mede o componente igualitário brasileiro permaneceu com valores intermediários durante quase 60 anos com um pequeno aumento no período que antecede o golpe militar, durante o governo de João Goulart -, só avançando substancialmente após a mais recente 
redemocratização. Ainda assim, os valores desse índice não atingiram a categoria máxima, sugerindo que na percepção dos codificadores do $\mathrm{V}$-Dem ainda permanecem limites importantes no que tange à promoção do componente igualitário da democracia brasileira.

O componente igualitário é composto de dois subíndices (proteção igualitária e distribuição igualitária de recursos). Para facilitar a visualização, dividimos os indicadores que compõem os subíndices em três figuras (Figuras 10, 11 e 12), a primeira apresentando resultados dos indicadores que compõem o primeiro subíndice, e as duas seguintes apresentando resultados para os indicadores do segundo subíndice, divididos em políticas públicas associadas à distribuição de poder e indicadores de distribuição de poder propriamente ditos.

\section{Figura 10}

\section{Evolução dos indicadores que compõem o índice de proteção igualitária}

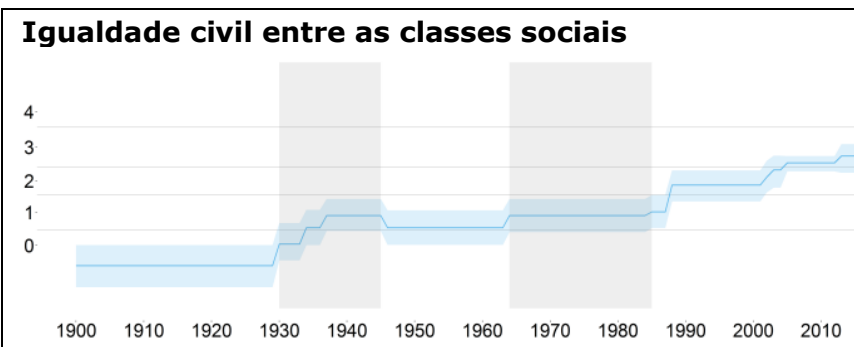

Questão: Os mais pobres gozam do mesmo nível de liberdades civis gozado pelos mais ricos? Respostas: 0. Muito menos. 1. Substancialmente menos. 2. Moderadamente menos. 3. Um pouco menos. 4. Mesmo nível de liberdades civis (Coppedge et al., 2016b, 225).

\section{Igualdade civil entre os grupos sociais}

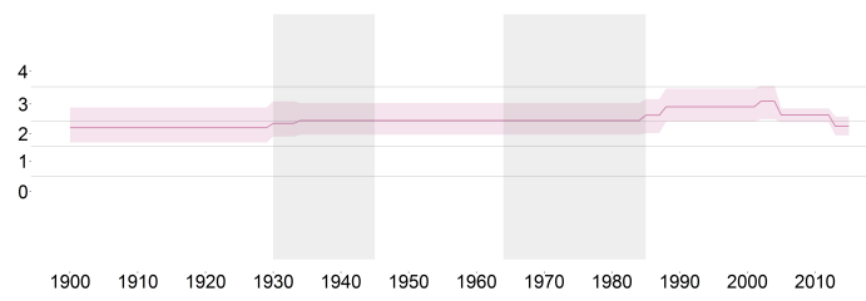

Questão: Todos os grupos sociais, definidos em termos de língua, etnia, religião, raça, região e casta desfrutam do mesmo nível de liberdade civil? Respostas: 0. Muito menos. 1. Substancialmente menos. 2. Moderadamente menos. 3. Um pouco menos. 4. Mesmo nível de liberdades civis entre os grupos sociais (Coppedge et al., 2016b, p. 225-226). 


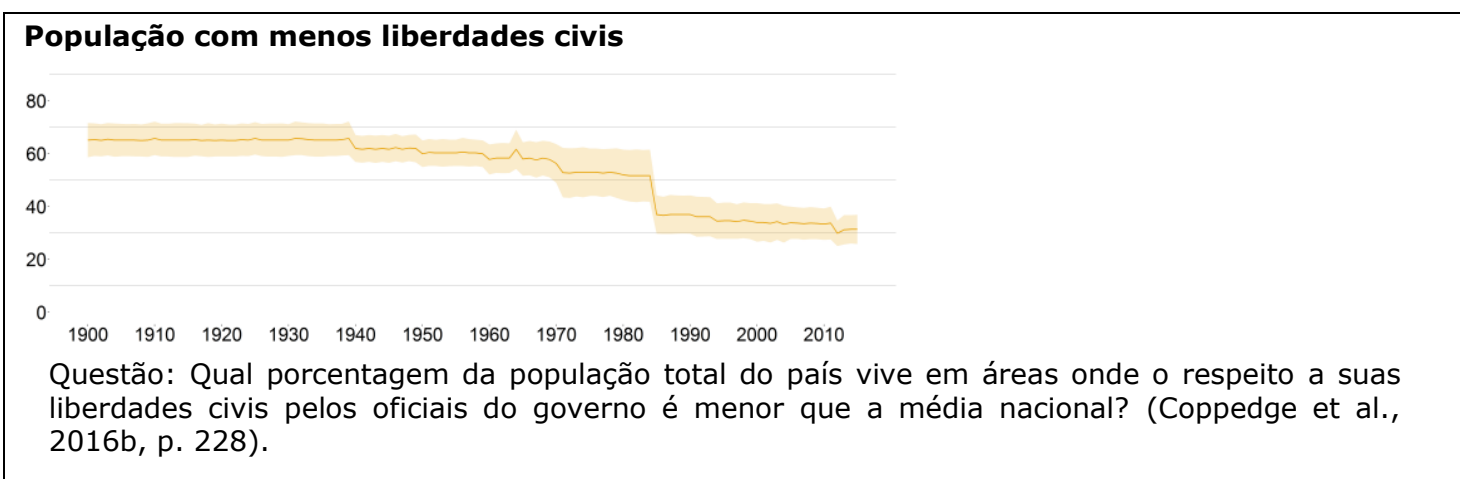

\section{Figura 11 \\ Evolução dos indicadores que compõem o índice de distribuição igualitária (políticas públicas)}

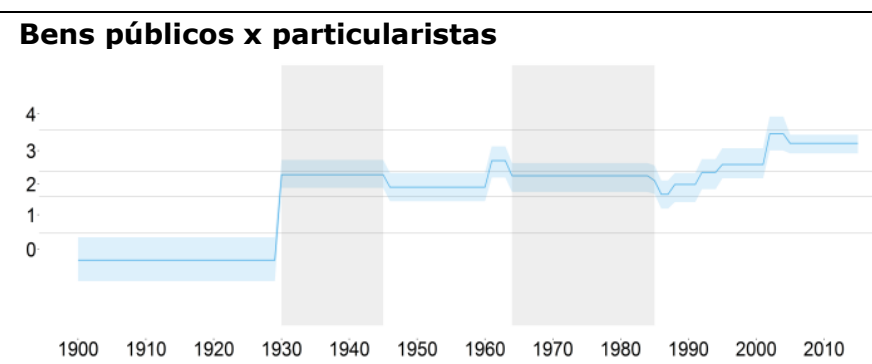

Questão: Considerando o perfil dos gastos sociais e com infraestrutura no orçamento nacional, quão "particularistas" são os gastos? Respostas: 0. Quase todo o gasto é particularista. 1. A maior parte é particularista, mas uma parte significativa é gasta com bens públicos. 2. Gastos são divididos entre particularistas e bens públicos. 3. A maior parte do gasto é em bens públicos, mas uma parte significativa é gasta com bens particularistas. 4. Quase todo o gasto é com bens públicos (Coppedge et al., 2016b, p. 195-196).

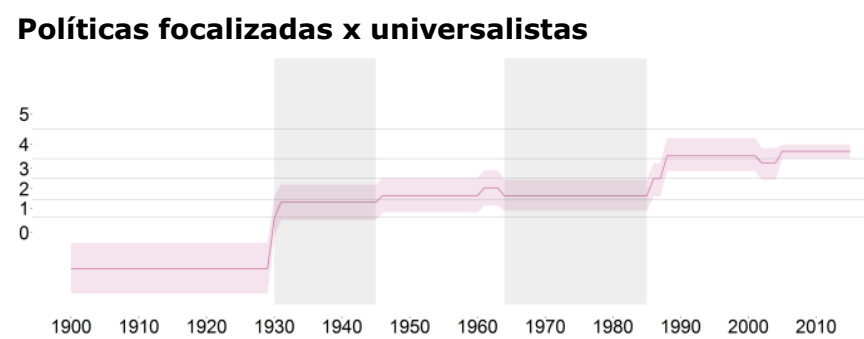

Questão: Quantos dos programas sociais são focalizados e quantos são universais? 0. Não há programas sociais estatais. 1. Quase todos os programas sociais são focalizados. 2. A maior parte dos programas é focalizada, mas uma parcela significativa é universal. 3. Os programas sociais são divididos em focalizados e universais. 4. A maior parte dos programas é universal, mas uma parcela significativa é focalizada. Quase todos os programas sociais são universais (Coppedge et al., 2016b, p. 196-197). 


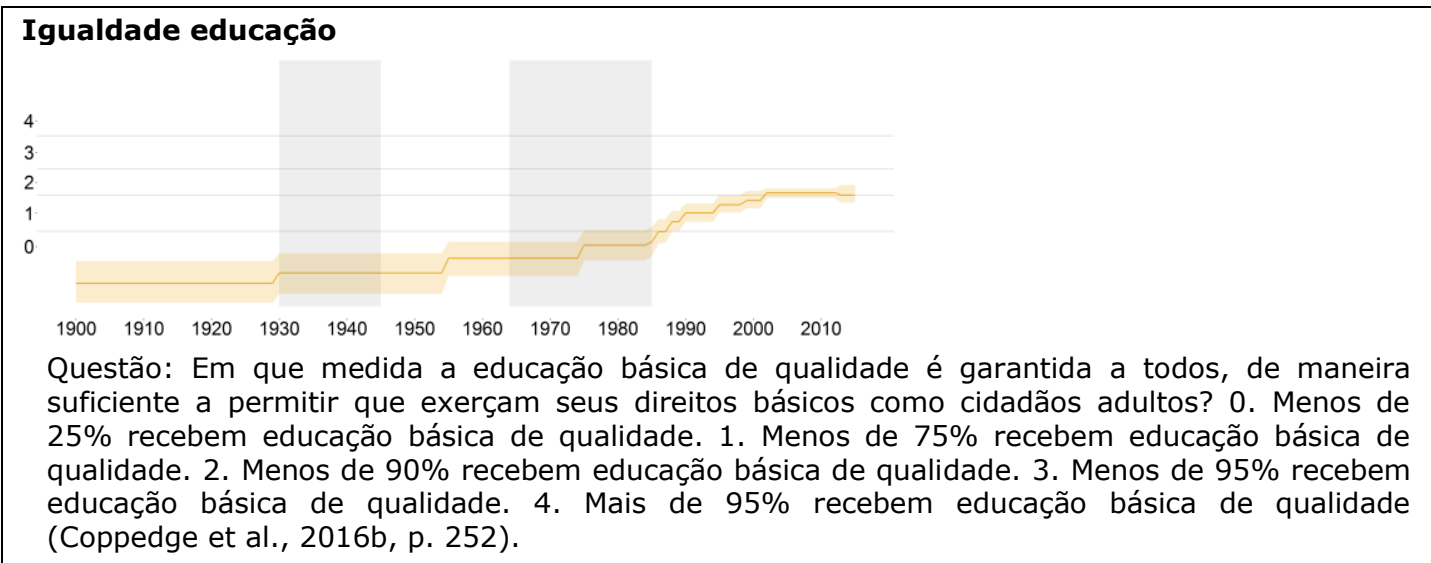

\section{Igualdade saúde}

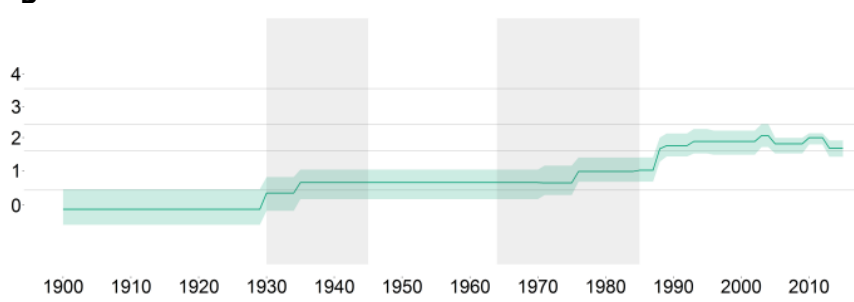

Questão: Em que medida a saúde básica de qualidade é garantida a todos, de maneira suficiente a permitir que exerçam seus direitos básicos como cidadãos adultos?

0 . Menos de $25 \%$ recebem saúde básica de qualidade.

1. Menos de $75 \%$ recebem saúde básica de qualidade.

2. Menos de $90 \%$ recebem saúde básica de qualidade.

3. Menos de $95 \%$ recebem saúde básica de qualidade.

4. Mais de $95 \%$ recebem saúde básica de qualidade (Coppedge et al., 2016b, p. 252).

\section{Figura 12 \\ Evolução dos indicadores que compõem o índice de distribuição igualitária (distribuição de poder)}

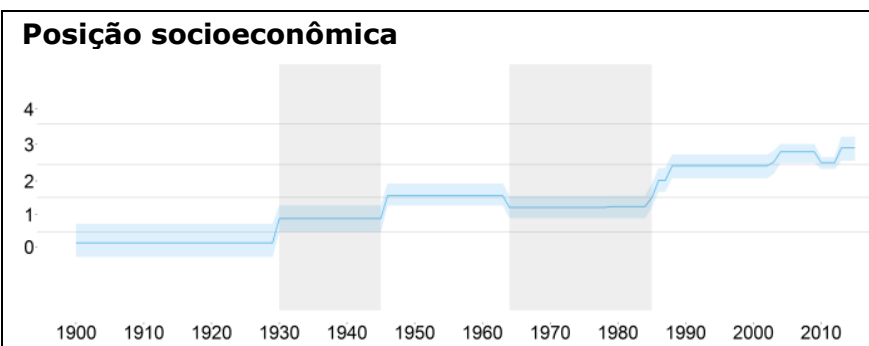

Questão: O poder político é distribuído de acordo com a posição socioeconômica dos indivíduos? 0 . Os mais ricos gozam de um virtual monopólio de poder político. 1 . Os mais ricos dominam o poder político. 2. Os mais ricos têm um poder político muito grande, e os mais pobres têm alguma influência apenas em assuntos a eles relacionados. 3. Os mais ricos têm mais poder político, mas os mais pobres têm um poder significativo. 4. Os mais ricos não gozam de mais poder político que os demais (Coppedge et al., 2016b, p. 249). 


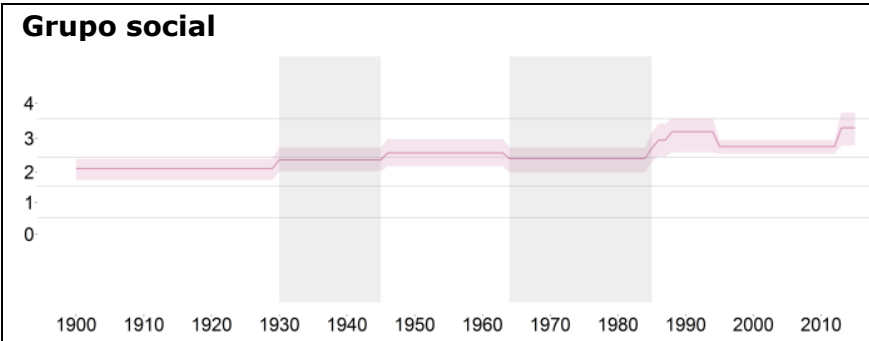

Questão: O poder político é distribuído de acordo com o grupo social dos indivíduos? 0 . Uma minoria detém o monopólio institucionalizado do poder político. 1. Algumas minorias detêm o monopólio institucionalizado do poder político. 2. Vários grupos detêm o monopólio institucionalizado do poder político. 3. Todos os grupos têm algum poder, mas alguns têm mais poder que outros; ou o monopólio não é institucionalizado. 4. Todos os grupos têm poder ou grupos sociais não são relevantes para a distribuição de poder político (Coppedge et al., 2016b, p. 250).

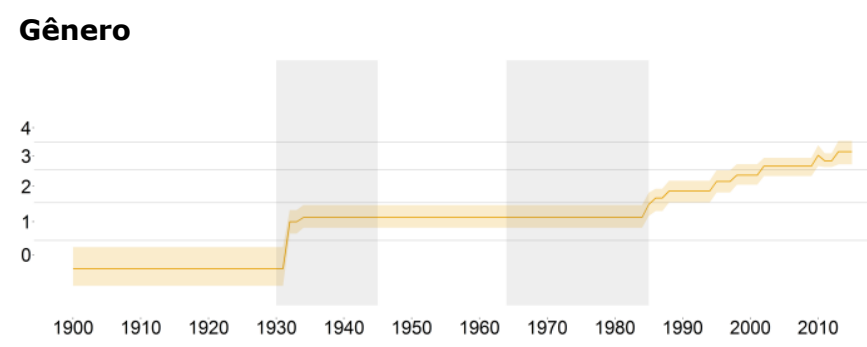

Questão: É o poder político distribuído de acordo com o gênero dos indivíduos? 0. Homens têm o monopólio do poder político. 1. Homens têm um poder dominante sobre a política, e mulheres têm um poder apenas marginal. 2. Homens têm muito mais poder que mulheres, mas mulheres têm influência em algumas áreas. 3. Homens têm mais poder que as mulheres. 4. Homens e mulheres têm poder igual (Coppedge et al., 2016b, p. 250).

Novamente explorando os indicadores em que a democracia brasileira se sai melhor e pior, observamos que os resultados mais baixos dentre os indicadores que compõem o componente igualitário da democracia são os da medida de igualdade no acesso à educação e à saúde. Especificamente, essas questões perguntavam em que medida a população obtinha uma educação/saúde de qualidade suficiente para garantir a sua plena participação como um cidadão na democracia. Durante a maior parte do século XX os resultados para o Brasil estiveram concentrados na categoria mínima - na qual se lê que a desigualdade é "extrema", com mais de $75 \%$ da população recebendo educação e saúde de baixa qualidade. Esses resultados começam a melhorar nos anos 1990, acompanhando os esforços de reorganização da educação pública brasileira e a universalização do acesso ao ensino fundamental (Lima, 2011), e a criação e consolidação do Sistema Único de Saúde. Nos últimos anos os resultados encontram-se na categoria 2, na qual ainda persistem desigualdades educacionais e de saúde, porém de maneira mais limitada, atingindo apenas de $10 \%$ a $25 \%$ dos brasileiros. 
A democracia brasileira se sai melhor no indicador que mede a orientação "pública" dos investimentos estatais em oposição a investimentos orientados para bens particularistas (Figura 11), ainda que os resultados apontem a percepção de que uma parte substantiva dos recursos públicos esteja orientada para os últimos. Com o advento do Estado nacional propriamente dito após o fim da Primeira República e o período sob Vargas, houve um primeiro incremento nos resultados do índice, passando da categoria que apontava o predomínio da orientação particularista para uma orientação mais equilibrada entre bens públicos e particulares. Recentemente (desde meados dos anos 1990) o indicador tomou uma orientação ascendente, tendo cruzado a fronteira para a categoria 3 nos anos 2000, o que representa a avaliação de que agora predomina a orientação pública da infraestrutura e dos investimentos públicos, ainda que orientações particularistas ainda sejam observadas em alguns casos.

Os demais indicadores incluídos no componente igualitário e desagregados na Figura 12 demonstram o importante papel que a Constituição de 1988 teve para a promoção e a consolidação dos direitos e instituições associados com a igualdade no Brasil. Mudanças substantivas só são observadas a partir do final da década de 1980, confirmando a contribuição da "Constituição cidadã" para a promoção e a garantia de direitos sociais no Brasil redemocratizado.

Em suma, a análise de outros componentes da democracia brasileira aponta, por um lado, para uma avaliação semelhante àquela observada com o índice de democracia eleitoral. A história brasileira segue uma espiral, com recuos autoritários seguidos de avanços democráticos - em relação tanto ao período autoritário quanto à experiência democrática anterior. De maneira semelhante, eles demonstram que o período democrático contemporâneo é o momento da história do Brasil em que se encontram os melhores resultados para todos os indicadores, evidenciando os importantes avanços do período atual. Por outro lado, quando vamos para além do índice de democracia eleitoral, no qual o Brasil obtém nota máxima, começa-se a perceber como, a despeito da estabilidade e da robustez do regime de competição eleitoral brasileiro, importantes limites ainda persistem para a democracia brasileira. Tais limites são observáveis principalmente nos componentes participativos e igualitários da democracia, sugerindo que a expansão dos direitos políticos e civis estabelecidos pela Constituição de 1988 avançou mais rapidamente que a expansão de outros direitos, representando um importante desafio para a democracia brasileira nos próximos anos.

\section{Dimensões adjacentes à democracia: corrupção e partidos políticos}

Um importante argumento na literatura internacional sustenta que a existência de práticas e instituições democráticas não é suficiente para a realização dos objetivos de desenvolvimento econômico e humano dos países (Norris, 2012). Seguindo uma tradição milenar na teoria política, autores enfatizam que o "bom governo" é tão ou até mesmo mais importante que a democracia para um país. Nós defendemos uma visão menos 
VARIEDADES DA DEMOCRACIA NO BRASIL

radical, e assumimos que, para a plena realização dos princípios e das potencialidades da democracia, o bom governo é necessário - ainda que não suficiente. Contemporaneamente, discussões sobre o bom governo se converteram em discussões sobre governance, especificamente entendida como a efetiva e eficaz aplicação dos recursos públicos e condução do governo. Uma de suas antíteses é a corrupção. Na primeira parte desta quarta seção nós analisamos uma série de indicadores que capturam a percepção dos codificadores do V-Dem sobre diferentes características associadas com a corrupção no Brasil.

Figura 13

Evolução dos índices e indicadores que compõem o índice de corrupção

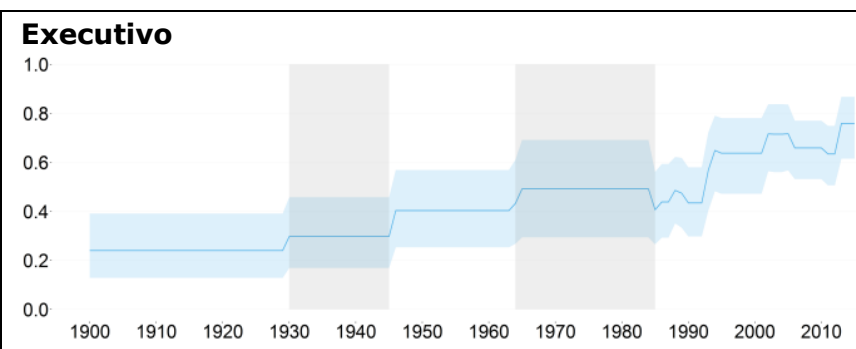

Questão: Quão rotineiramente membros do Executivo oferecem favores em troca de suborno, recompensas ou outros incentivos materiais, e quão frequentemente eles roubam, fraudam ou se apropriam de recursos públicos para uso pessoal e familiar? Esclarecimento: O índice varia de mais corrupção (valores mais baixos) para menos corrupção (valores mais altos) (Coppedge et al., 2016b, p. 67).

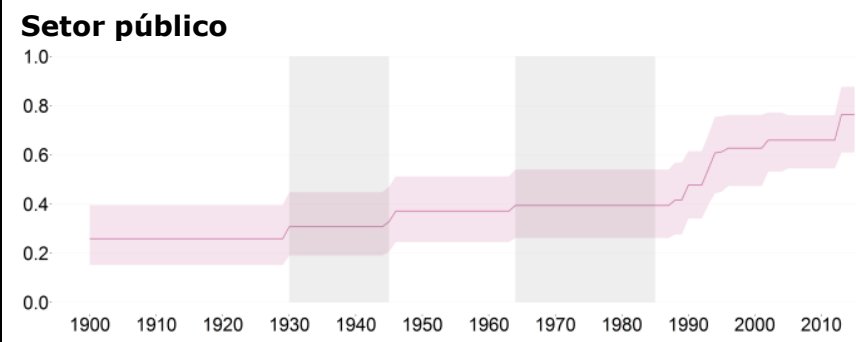

Questão: Quão rotineiramente funcionários públicos oferecem favores em troca de suborno, recompensas ou outros incentivos materiais, e quão frequentemente eles roubam, fraudam ou se apropriam de recursos públicos para uso pessoal e familiar? Esclarecimento: $O$ índice varia de mais corrupção (valores mais baixos) para menos corrupção (valores mais altos) (Coppedge et al., 2016b, p. 67). 


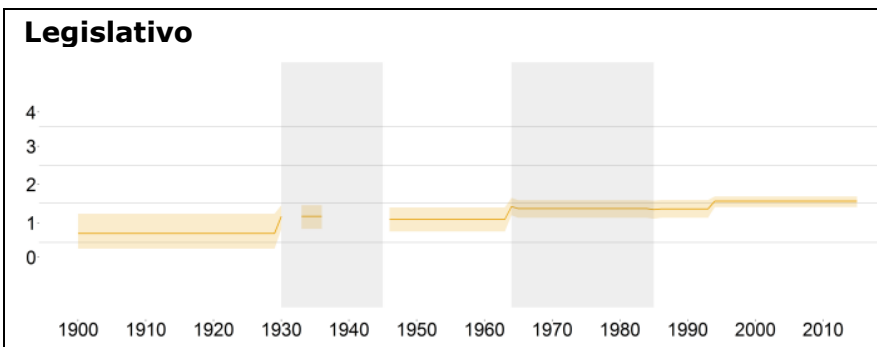

Questão: Os membros do Legislativo abusam de sua posição para conseguir ganhos financeiros? Respostas: 0. Sempre. A maioria dos legisladores o faz. 1. Normalmente. Muitos legisladores o fazem. 2. Algumas vezes. Alguns legisladores o fazem. 3. Raramente. Poucos legisladores o fazem. 4. Não, nunca (Coppedge et al., 2016b, p. 177).

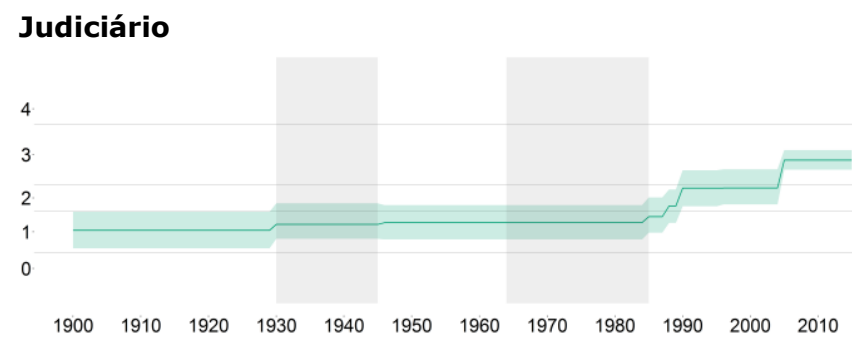

Questão: Quão rotineiramente indivíduos ou empresas fazem pagamentos indevidos ou praticam suborno para influenciar a velocidade ou o resultado de uma decisão judicial? 0. Sempre. 1. Normalmente. 2. Em metade das vezes. 3. Raramente. 4. Nunca (Coppedge et al., 2016b, p. 201).

$\mathrm{Na}$ Figura 13 observa-se o comportamento dos dois índices e dos dois indicadores que são combinados para formar o índice de corrupção política do V-Dem. Tais índices e indicadores medem a corrupção nas múltiplas dimensões do Estado, a saber: na burocracia estatal, no Executivo, no Legislativo e no Judiciário. Um elemento que salta aos olhos na Figura 13 é o fato de que em praticamente todos os gráficos os resultados se concentram na parte inferior do gráfico na maior parte do tempo (lá permanecem no caso do indicador que mede a corrupção no Legislativo), mais próximos dos valores de pior desempenho que do seu oposto. Assim como nos demais gráficos apresentados, há uma importante melhora observada desde o fim dos anos 1980 e começo dos anos 1990, em linha com interpretações contemporâneas das instituições brasileiras que apontam importantes transformações nessa dimensão da vida política nacional, com o incremento do poder e da atuação efetiva das instituições de controle e a consequente diminuição da corrupção - ainda que esta permaneça elevada (Praça, 2011; Melo e Pereira, 2013).

Outra dimensão adjacente da democracia brasileira medida pelo V-Dem é o sistema partidário e os partidos que o compõem. Em larga medida, a evolução recente do índice de institucionalização partidária (não mostrado) se alinha com as impressões 
VARIEDADES DA DEMOCRACIA NO BRASIL

dos especialistas na área que têm apontado a institucionalização dos partidos e do sistema partidário brasileiro após um início turbulento no momento imediatamente posterior à redemocratização (Mainwaring, Power e Bizzarro, no prelo). Os resultados brasileiros para o período recente encontram-se bastante próximos à fronteira da categoria máxima.

Figura 14

Evolução dos indicadores que compõem o índice de institucionalização partidária

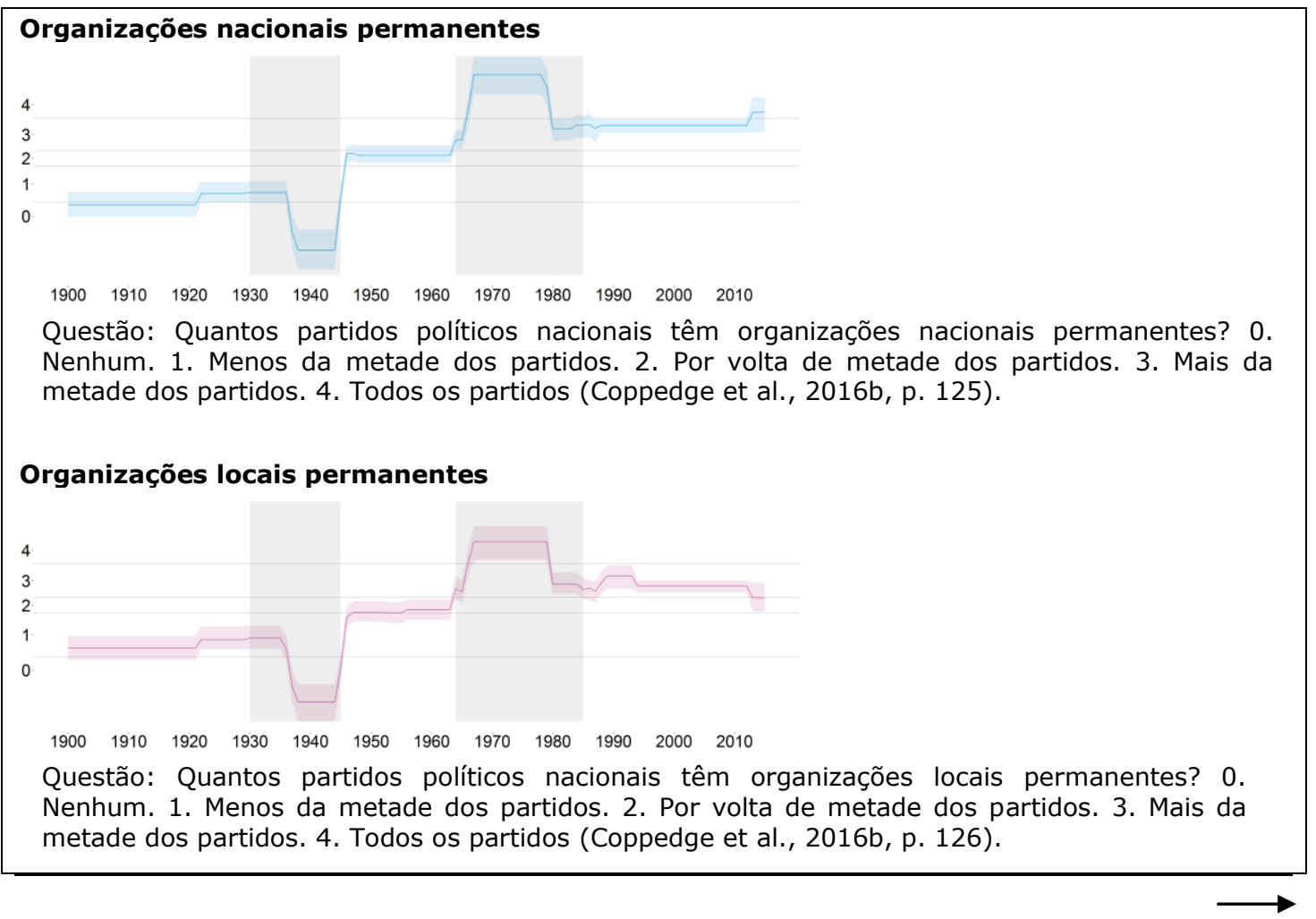




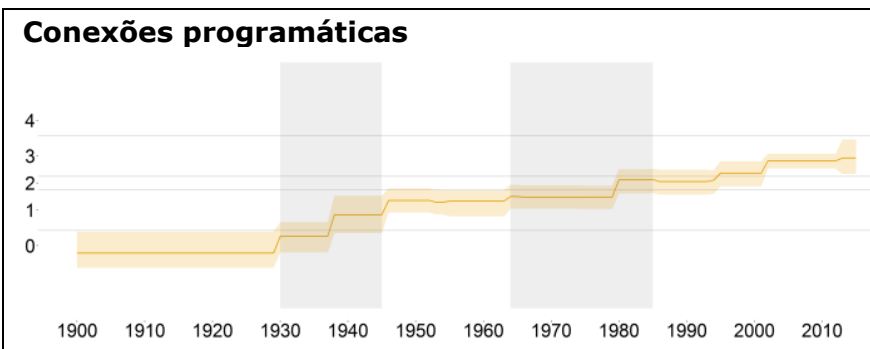

Questão: Entre os principais partidos, qual é a forma mais comum de ligação com os eleitores? 0 . Clientelista. Eleitores são recompensados com bens, dinheiro e/ou empregos. 1. Mistura de clientelista e localista. 2. Localista. Eleitores são recompensados com bens coletivos locais, como poços, estradas. 3. Mistura de localista e programática. 4. Programática. Eleitores respondem à posição do partido sobre assuntos nacionais, seu programa e sua ideologia (Coppedge et al., 2016b, p. 126).

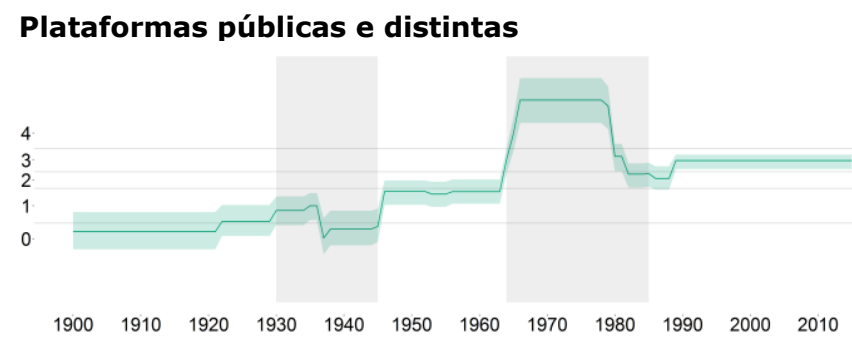

Questão: Quantos partidos políticos com representação no Legislativo nacional têm plataformas políticas disponíveis publicamente e que são distintas das demais? 0. Nenhum. 1. Menos da metade dos partidos. 2. Por volta de metade dos partidos. 3. Mais da metade dos partidos. 4. Todos os partidos (Coppedge et al., 2016b, p. 127).

\section{Coesão no Legislativo

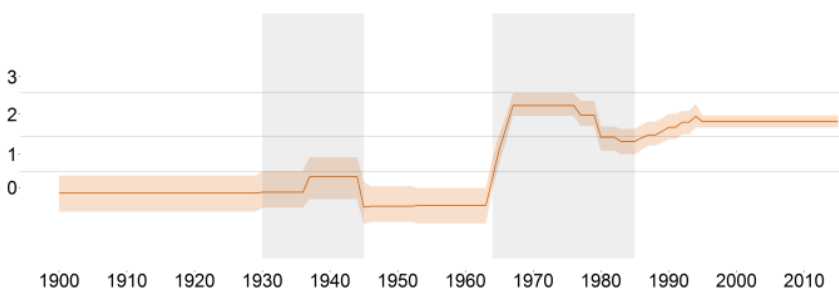

Questão: É normal que membros do partido no Legislativo votem todos na mesma direção em leis importantes? 0. Não. Coesão partidária é muito baixa. 1. Raramente. Defecções são comuns. 2. Na maioria das vezes eles votam juntos. 3. Sim. Coesão partidária é muito alta (Coppedge et al., 2016b, p. 128).

Historicamente, os dados apontam que o momento de maior institucionalização partidária ocorreu sob a ditadura militar. Aqui uma explicação é importante. As questões sobre a força das organizações partidárias e sobre as dinâmicas de suas interações que compõem o indicador do V-Dem pedem aos codificadores que avaliem os partidos "em média". No contexto do bipartidarismo brasileiro, no qual apenas Arena e MDB 
VARIEDADES DA DEMOCRACIA NO BRASIL

competiam, essa média incorpora evidentemente uma variação muito menor nos indicadores que nos períodos multipartidários. Isso se torna evidente quando desagregamos o índice (Figura 14), e percebe-se que os indicadores que empurram o índice de institucionalização partidária para cima são aqueles mais sensíveis a essa medição ponderada dos partidos - como os que perguntam em que medida os partidos têm plataformas diferenciadas, em que medida os partidos penetram o território nacional de maneira homogênea ou têm organizações nacionais estabelecidas. Contudo, esse resultado não é apenas um artifício matemático. Como diversos autores demonstraram, Arena e MDB tinham forte penetração territorial e constituíram amplas e diferenciadas organizações partidárias, e, ainda que contassem com pouca influência efetiva nos rumos do Executivo, suas ações tinham importantes consequências para o funcionamento do Legislativo e da política municipal (Grinberg, 2009; Kerbauy, 2000; Kinzo, 1988).

Por fim, é interessante notar como o índice é também sensível às variações observadas nos períodos anteriores, com os resultados baixos observados durante a maior parte da Primeira República - quando partidos nacionais estavam ausentes (Chacon, 1981) -, o pequeno incremento que se segue à fundação do Partido Comunista Brasileiro em 1922 e depois da intensa mobilização política dos primeiros anos do governo Vargas, e finalmente a supressão dos partidos durante o Estado Novo, quando o indicador regride ao nível mínimo.

\section{Um exercício comparativo: o Brasil e seus vizinhos}

Um importante diferencial do V-Dem é a combinação de indicadores desagregados, criados a partir de regras transparentes e precisas, para quase duas centenas de países do mundo nos últimos 115 anos. Nas seções anteriores nós exploramos a desagregação e o alcance dos dados do projeto sobre o Brasil. Nesta seção realizamos um pequeno esforço comparativo, olhando os resultados obtidos pelo Brasil nas principais dimensões da democracia aqui discutidas (democracia eleitoral e componentes liberal, deliberativo, participativo e igualitário) à luz dos resultados obtidos para alguns dos seus vizinhos na América do Sul.

Dada a presença de regimes com importantes diferenças dentro do continente, nós selecionamos dois casos importantes para obter uma figura mais precisa da posição do Brasil em relação aos seus vizinhos. As linhas da Figura 15 comparam os dados para o Brasil com os da Venezuela e do Chile. Escolhemos esses dois países pois representam no continente duas situações diversas. Por um lado, a experiência chilena é apontada como bem-sucedida na restauração do regime democrático após o fim do autoritarismo do general Pinochet (Mainwaring e Pérez-Liñán, 2015). Por outro lado, a experiência venezuelana contrasta muito com a história do Cone Sul: a Venezuela não experimentou um recuo autoritário em meados do século XX como muitos dos seus vizinhos, nem observou uma melhora em seus indicadores no período recente, tendo na verdade 
experimentado a ascensão de um regime de tipo "autoritarismo competitivo" desde 1998 (Levitsky e Way, 2010).

Figura 15

Evolução do índice de democracia eleitoral e dos demais componentes da democracia no Brasil, no Chile e na Venezuela

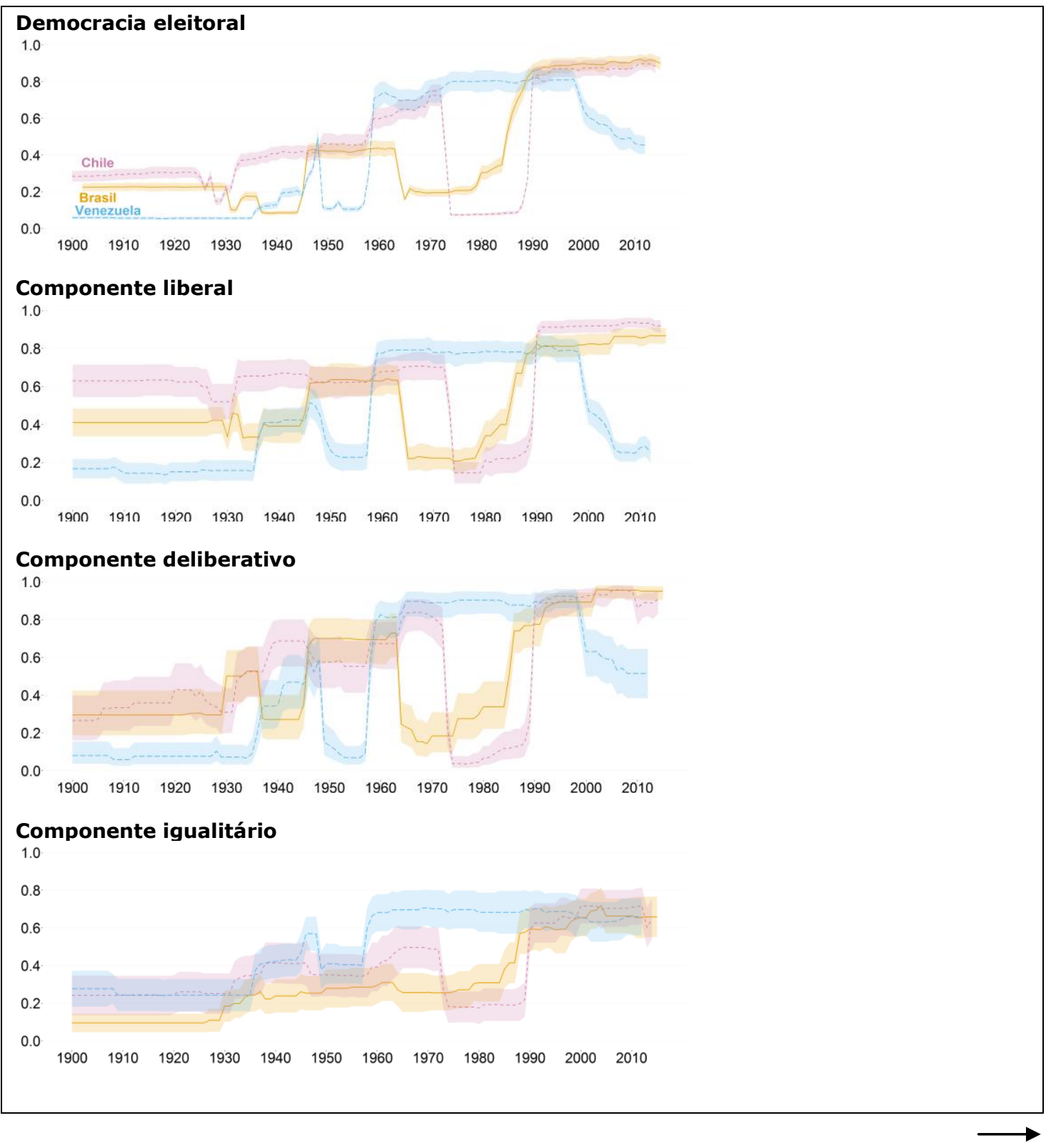




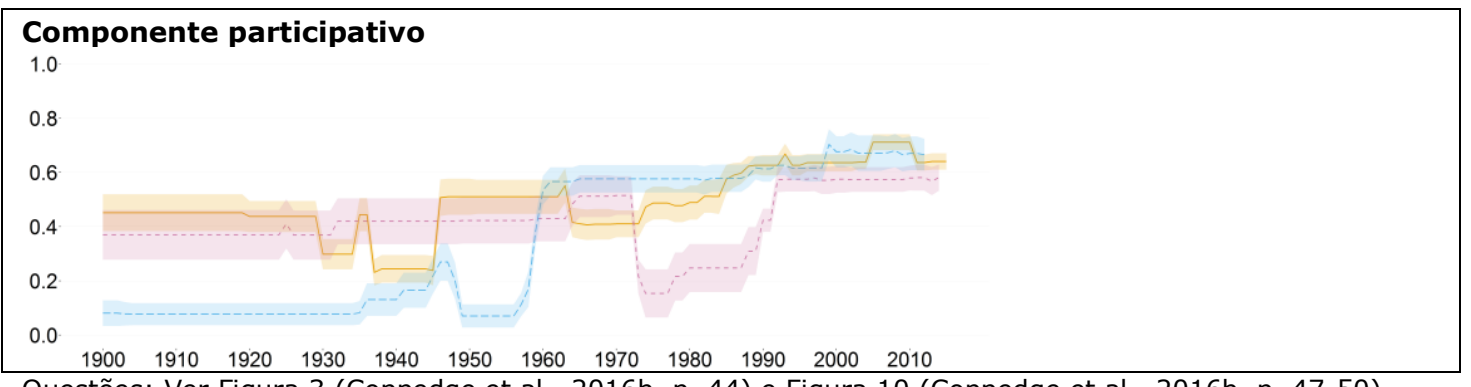

Questões: Ver Figura 3 (Coppedge et al., 2016b, p. 44) e Figura 10 (Coppedge et al., 2016b, p. 47-50).

Na Figura 15 percebem-se as diferenças históricas e contemporâneas dos regimes. Por um lado, a deterioração dos indicadores de democracia na Venezuela mostrada no indicador de democracia eleitoral também é observável nos componentes liberal e deliberativo da democracia, ainda que esta não ocorra nos componentes igualitário e participativo, que mantêm resultados constantes desde o chamado "Pacto de Punto Fijo", que estabeleceu as bases do regime venezuelano organizado em 1958 (Coppedge, 1997). Percebe-se, portanto, o alinhamento entre os dados do V-Dem e as interpretações correntes que apontam a ambiguidade do regime venezuelano desde 1998 (Mainwaring, 2012).

Brasil e Chile têm dinâmicas históricas semelhantes e pequenas diferenças contemporâneas. Os países experimentaram tendências semelhantes na sucessão de regimes autoritários e democráticos. Recentemente, a democracia chilena apresenta resultados mais elevados no componente liberal do regime, que mede as liberdades individuais e o império da lei, enquanto a democracia brasileira tem resultados mais elevados no componente participativo da democracia. Não há diferenças perceptíveis entre Brasil e Chile no que tange ao componente igualitário da democracia, assim como seus valores não se diferenciam dos valores observados para a Venezuela. Isso demonstra interessantes nuances das principais democracias do continente hoje em dia, algo impossível de observar com outras ferramentas de análise previamente existentes.

\section{Conclusão}

Os dados aqui apresentados produzem uma figura complexa da realidade política brasileira histórica e contemporânea. A lógica em espiral dos regimes políticos brasileiros, traço marcante da trajetória política do Brasil (Cruz e Martins, 1983), encontra-se hoje em seu momento mais pujante. O índice que mede a democracia eleitoral no Brasil apresenta os melhores resultados da história, colocando o país dentro do grupo dos países mais democráticos do mundo nessa dimensão. A redemocratização do Brasil após 1985 provou-se substancial no que tange à dimensão eleitoral da democracia. Trinta 
anos após o fim da ditadura militar, contestação e participação compõem o dia a dia da política brasileira.

Os dados aqui apresentados também reforçam a cautela com a qual muitos pesquisadores tendem a tratar o período da chamada Primeira República / República Velha. Os importantes limites à competição eleitoral, a ausência de diversos direitos e instituições que se mostraram fundamentais para a posterior consolidação da democracia no Brasil e as características da política oligárquica e regionalizada do período sugerem que o primeiro período democrático de fato no Brasil começou mesmo em 1945, sendo interrompido abruptamente em 1964 pelo golpe militar.

A consolidação da democracia eleitoral foi acompanhada de importantes avanços em outras dimensões do regime. Ainda que existam claros limites ao império da lei e à garantia das liberdades individuais, principalmente devido às desigualdades sociais, os índices apresentados que tratam desses assuntos mostram a substancial evolução histórica desses indicadores. O Estado brasileiro hoje respeita seus cidadãos e as leis mais que em qualquer outro momento de sua história e o rol de direitos individuais garantidos é abrangente. Ao mesmo tempo, o embate político transcorre dentro da normalidade democrática e as disputas são resolvidas, contidas e debatidas dentro dos mecanismos institucionais de deliberação política democrática.

Os avanços nos índices de democracia no Brasil a partir dos vários componentes propostos pelo $\mathrm{V}$-Dem têm magnitude desigual contudo. Enquanto nos componentes eleitoral, deliberativo e liberal da democracia os indicadores para o Brasil observam valores elevados em perspectiva tanto histórica quanto comparada, o país ainda tem mais a avançar no que tange a outras dimensões do regime, sejam elas centrais ou adjacentes. Os gargalos para o desenvolvimento democrático no Brasil encontram-se principalmente no componente igualitário da democracia, que ainda apresenta importantes desigualdades sociais e econômicas com consequências políticas para o regime democrático, e no componente participativo. Embora experiências participativas recentes tenham sido implementadas, a dimensão participativa ainda se encontra limitada no Brasil.

Da mesma forma se apresentam os resultados para o índice que mede a corrupção no Brasil e a força do sistema partidário. Novamente observam-se importantes avanços históricos para os índices brasileiros que tratam desses temas, avanços que ainda não foram capazes de superar o déficit histórico que o país apresenta no combate à corrupção e na construção de um sistema partidário institucionalizado. O jornalismo contemporâneo brasileiro não desmente essa observação: os escândalos de corrupção envolvendo grande parte da classe política, tanto no Executivo quanto no Legislativo, e importantes setores da burocracia estatal demonstram que, a despeito dos avanços dos mecanismos de controle e da diminuição da corrupção apontada pela literatura, há ainda um longo caminho a percorrer nesse sentido para a democracia brasileira. Os impactos dos escândalos recentes no sistema partidário fornecem evidência semelhante, demonstrando que os partidos políticos não são capazes de garantir a própria 
VARIEDADES DA DEMOCRACIA NO BRASIL

organização e atividade sem recorrer à corrupção, ao mesmo tempo em que não são capazes de garantir a manutenção de sua legitimidade e seu apoio junto à população.

Esse é, portanto, um cenário ambíguo, em que avanços importantes coexistem com práticas que limitam a qualidade da democracia no Brasil. Nós acreditamos que a compreensão de onde estão os limites contemporâneos ao regime democrático no Brasil pode ajudar no seu desenvolvimento. Ao mesmo tempo, a análise comparativa permite explorar as experiências e dinâmicas internacionais, oferecendo alternativas importantes aos formuladores de políticas públicas sobre os alvos a serem atingidos. Os dados do VDem aqui apresentados dão conta dessas duas tarefas de maneira única no cenário internacional contemporâneo. Eles também oferecem importantes ferramentas a pesquisadores, professores e estudantes de todos os níveis para entender a história do Brasil em suas múltiplas faces. Esperamos que este artigo tenha demonstrado essas potencialidades.

Fernando Bizzarro - Harvard University. E-mail: <fbizzarroneto@g.harvard.edu>.

Michael Coppedge - University of Notre Dame. E-mail: <coppedge.1@nd.edu>.

\section{Referências bibliográficas}

AVRITZER, L. "Conferências nacionais: ampliando e redefinindo os padrões de participação social no Brasil." IPEA: Textos para Discussão, n 1.739, maio 2012.

CARONE, E. A República Velha. São Paulo: Difusão Europeia do Livro, 1970.

A Segunda República (1930-1937). São Paulo: Difusão Europeia do Livro, 1973.

CHACON, V. História dos partidos brasileiros: discurso e práxis dos seus programas. Brasília: Editora Universidade de Brasília, 1981.

COPPEDGE, M. Strong parties and lame ducks: presidential partyarchy and factionalism in Venezuela. Stanford: Stanford University Press, 1997.

. Democratization and research methods. Cambridge: Cambridge University Press, 2012.

CoppedGE, M., et al. "Conceptualizing and measuring democracy: a new approach". Perspectives on Politics, vol. 9, n², p. 247-267, jun. 2011.

Coppedge, M. et al. Varieties of Democracy Dataset v6. Varieties of Democracy Project. 2016a. . Varieties of Democracy Codebook v6. Varieties of Democracy Project: Project Documentation Paper Series, 2016b. . Varieties of Democracy Methodology v6. Varieties of Democracy Project: Project Documentation Paper Series, 2016c.

CRUZ, S. V.; MARTINS, C. E. De Castello a Figueiredo: uma incursão na pré-história da abertura. In: SORJ, B.; ALmeIDA, M. H. T. (eds.). Sociedade e política no Brasil pós-64. São Paulo: Brasiliense, 1983. 
DAHL, R. A. Polyarchy: participation and opposition. New Haven: Yale University Press, 1971.

DAHL, R. A. Dilemmas of pluralist democracy autonomy vs. control. New Haven: Yale University Press, 1982.

. Um prefácio à teoria democrática. Rio de Janeiro: Jorge Zahar Editor, 1989.

DRYZEK, J. S. Foundations and frontiers of deliberative governance. Oxford: Oxford University Press, 2010.

Gaspari, E. A ditadura encurralada. São Paulo: Companhia das Letras, 2004.

Grinberg, L. Partido político ou bode expiatório: um estudo sobre a Aliança Renovadora Nacional, Arena (1965-1979). Rio de Janeiro: Faperj, Mauad X, 2009.

HELD, D. Models of democracy. Stanford: Stanford University Press, 1987.

Kerbauy, M. T. M. A morte dos coronéis : política interiorana e poder local. Araraquara: Cultura Acadêmica Editora, 2000.

KInzo, M. D. G. Oposição e autoritarismo: gênese e trajetória do MDB, 1966-1979. São Paulo: Edições Vértice, Editora Revista dos Tribunais, Idesp, 1988.

. "A democratização brasileira: um balanço do processo político desde a transição". São Paulo em Perspectiva, vol. 15, n 4, p. 3-12, dez. 2001.

LAMOUNIER, B. O "Brasil autoritário" revisitado: o impacto das eleições sobre a abertura. In: STEPAN, A. C. (ed.). Democratizando o Brasil. Rio de Janeiro: Paz e Terra, 1988.

LEVITSKY, S.; WAY, L. Competitive authoritarianism: hybrid regimes in the post-Cold War era. Cambridge: Cambridge University Press, 2010.

LIJPhART, A. Patterns of democracy: government forms and performance in thirty-six countries. New Haven: Yale University Press, 1999.

LIMA, L. C. A. "Da universalização do ensino fundamental ao desafio de democratizar o ensino médio em 2016: o que evidenciam as estatísticas?". Revista Brasileira de Estudos Pedagógicos, vol. 92, nº 231 , p. 268-284, 2011.

LimongI, F. "Eleições e democracia no Brasil: Victor Nunes Leal e a transição de 1945". Dados, vol. $55, n^{\circ} 1$, p. 37-69, 2012.

Linz, J. J.; Stepan, A. C. The breakdown of democratic regimes. Baltimore: Johns Hopkins University Press, 1978.

MacPherson, C. B. The life and times of liberal democracy. Oxford: Oxford University Press, 1977.

MAINWARING, S. "From representative democracy to participatory competitive authoritarianism: Hugo Chávez and Venezuelan politics". Perspectives on Politics, vol. 10, n 4, p. 955-967, dez. 2012.

Mainwaring, S.; Pérez-LiñÁn, A. "Cross-currents in Latin America". Journal of Democracy, vol. 26, nº 1 , p. $114-127,2015$.

Mainwaring, S.; Power, T.; Bizzarro, F. Brazil: the uneven institutionalization of a party system. In: MAINWARING, S. (ed.). Party system institutionalization, decay, and collapse. Cambridge: Cambridge University Press, no prelo. 
VARIEDADES DA DEMOCRACIA NO BRASIL

Melo, M. A.; PereirA, C. Making Brazil work: checking the president in a multiparty system. New York: Palgrave Macmilan, 2013.

MILL, J. S. Considerações sobre o governo representativo. São Paulo: Ibrasa, 1964.

MunCK, G. L.; VerkUILEN, J. "Conceptualizing and measuring democracy: evaluating alternative indices". Comparative Political Studies, vol. 35, n 1, p. 5-34, 1 fev. 2002.

NicolaU, J. M. Eleições no Brasil: do Império aos dias atuais. Rio de Janeiro: Zahar, 2012.

NoRRIS, P. Making democratic governance work: how regimes shape prosperity, welfare, and peace. Cambridge: Cambridge University Press, 2012.

O'DONNELL, G.; SCHMITTER, P. Transitions from authoritarian rule: tentative conclusions about uncertain democracies. Baltimore: The Johns Hopkins University Press, 1989.

PAteman, C. Participation and democratic theory. Cambridge: Cambridge University Press, 1970.

Pemstein, D.; Tzelgov, E.; WANG, Y.-T. Evaluating and improving item response theory models for cross-national expert surveys. Varieties of Democracy Institute: Working Paper Series, 2015.

Porto, W. C. O voto no Brasil: da colônia à 6a República. Rio de Janeiro: Topbooks, 2002.

PraçA, S. "Corrupção e reforma institucional no Brasil, 1988-2008". Opinião Pública, vol. 17, n 1, p. 137-162, jun. 2011.

RiCCI, P.; ZULINI, J. P. "'Beheading', rule manipulation and fraud: the approval of election results in Brazil, 1894-1930". Journal of Latin American Studies, vol. 44, n 3, p. 495-521, ago. 2012.

. "Partidos, competição política e fraude eleitoral: a tônica das eleições na Primeira República". Dados, vol. 57, n² 2, p. 443-479, jun. 2014.

RochA, A. S. "Genealogia da Constituinte: do autoritarismo à democratização". Lua Nova: Revista de Cultura e Política, n 88, p. 29-87, jan. 2013.

SAntos, W. G. Sessenta e quatro: anatomia da crise. São Paulo: Vértice, 1986.

Schumpeter, J. A. Capitalism, socialism and democracy. London: Routledge, 2013.

Skidmore, T. E. Brasil de Getúlio Vargas a Castelo Branco - 1930-1964. Rio de Janeiro: Paz e Terra, 1975.

SOARES, G. A. D. Sociedade e política no Brasil: desenvolvimento, classe e política durante a Segunda República. São Paulo: Difusão Europeia do Livro, 1973.

SolA, L. O golpe de 37 e o Estado Novo. In: MotTA, C. G. (ed.). Brasil em perspectiva. São Paulo: Difusão Europeia do Livro, p. 162-226, 1968.

SouzA, M. C. C. C. O processo político partidário na República Velha. In: MotTA, C. G. (ed.). Brasil em perspectiva. São Paulo: Difusão Europeia do Livro, p. 162-226, 1968.

TEORELL, J., et al. "Measuring high level democratic principles using the V-Dem data". International Political Science Review, vol. 37, no 5, 2016.

TRIER, S.; JACKMAN, S. "Democracy as a latent variable". American Journal of Political Science, vol. 52, n० 1, p. 201-217, 2008. 


\begin{abstract}
Resumo
Variedades da Democracia no Brasil

Neste artigo apresentamos resultados coletados pelo projeto Variedades da Democracia para o Brasil. Descrevemos a evolução histórica da democracia brasileira entre 1900 e 2015 enfocando seus cinco principais componentes (eleitoral, liberal, participativo, deliberativo e igualitário) e duas dimensões adjacentes ao regime (corrupção e partidos políticos). Por fim, nós comparamos os dados para o Brasil com resultados obtidos para outros países da América do Sul. A análise dos dados aponta: a. a existência de uma trajetória "em espiral" dos regimes políticos no Brasil, na qual novas experiências democráticas tendem a superar experiências anteriores em todos os quesitos; b. os avanços e limites da experiência democrática contemporânea em que se combinam bons resultados nos indicadores eleitoral, liberal e deliberativo da democracia, e resultados menos elevados nos componentes igualitário e participativo do regime, bem como em suas dimensões adjacentes.
\end{abstract}

Palavras-chave: democracia; Brasil; democracia eleitoral; corrupção; partidos políticos

\title{
Abstract
}

Varieties of Democracy in Brazil

In this article, we present results for Brazil collected by the Varieties of Democracy project. We describe the historical evolution of democracy in Brazil from 1900 to 2012, focusing on its five main components (electoral, liberal, participatory, deliberative, and egalitarian), and on two adjacent dimensions of the regime (corruption and political parties). Lastly, we compare the data for Brazil with similar results for other South American countries. The results suggest that: a. a "spiral" trajectory has characterized Brazilian political regimes, so that new democratic experiences have always been more democratic in all dimensions than previous ones; b. the contemporary democratic experience combines positive results obtained in the electoral, liberal, and deliberative components of democracy, with less positive results observed in the egalitarian and participatory components of democracy, as well as in its adjacent dimensions.

Keywords: democracy; Brazil; electoral democracy; corruption; political parties

\section{Resumen}

Variedades de la Democracia en Brasil

En este artículo se presentan los resultados recogidos por el proyecto Variedades de Democracia para Brasil. Se describe la evolución histórica de la democracia brasileña entre 1900 y 2015, centrándose en cinco componentes principales (electoral, liberal, participativo, deliberativo e igualitario) y dos dimensiones adyacentes al régimen (corrupción y partidos políticos). Por último, se comparan los datos de Brasil con los resultados obtenidos para otros países de América del Sur. Los resultados sugieren: a. la existencia de una trayectoria "espiral" de los regímenes políticos en Brasil, donde las nuevas experiencias democráticas tienden a superar a la experiencia previa en todos los aspectos; b. los avances y límites de la experiencia democrática contemporánea que combina buenos resultados en los componentes electoral, liberal y deliberativo, con peores resultados en los componentes igualitario y participativo del sistema, así como en sus dimensiones adyacentes.

Palabras clave: democracia; Brasil; democracia eleitoral; corrupción; partidos políticos 
VARIEDADES DA DEMOCRACIA NO BRASIL

\section{Résumé}

Variétés de la Démocratie au Brésil

Dans cet article, nous présentons les résultats recueillis par le projet Variétés de la Démocratie pour le Brésil. Nous décrivons l'évolution historique de la démocratie au Brésil de 1900 à 2015, en nous concentrant sur ses cinq composantes principales (électorale, libérale, participative, délibérative, et égalitaire), et sur deux dimensions adjacentes du régime (la corruption et les partis politiques). Finalement, nous comparons les données pour le Brésil avec des résultats similaires pour les autres pays d'Amérique du Sud. Les résultats suggèrent: a. qu'une trajectoire «en spirale» a caractérisé les régimes politiques brésiliens, dans laquelle de nouvelles expériences démocratiques dépassent les expériences précédentes, dans toutes leurs dimensions; b. que l'expérience démocratique contemporaine combine des résultats positifs obtenus dans les composantes électorale, libérale, et délibérative de la démocratie, avec des résultats moins positifs observés dans les composantes égalitaire et participative de la démocratie, ainsi que dans ses dimensions adjacentes.

Mots-clés: démocratie; Brésil; démocratie électorale; corruption; partis politiques

Artigo submetido à publicação em 16 de novembro de 2015. Versão final aprovada em 24 de fevereiro de 2017. 